NATIONAL LABORATORY

\title{
Phenylnaphthalene as a Heat Transfer Fluid for Concentrating Solar Power: High-Temperature Static Experiments
}

May 2012

Prepared by

J.R. Bell

R.A. Joseph III

J. McFarlane

A.L. Qualls

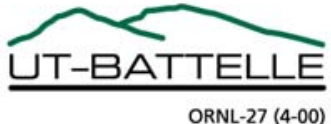




\section{DOCUMENT AVAILABILITY}

Reports produced after January 1, 1996, are generally available free via the U.S. Department of Energy (DOE) Information Bridge.

Web site http://www.osti.gov/bridge

Reports produced before January 1, 1996, may be purchased by members of the public from the following source.

National Technical Information Service
5285 Port Royal Road
Springfield, VA 22161
Telephone 703-605-6000 (1-800-553-6847)
TDD 703-487-4639
Fax 703-605-6900
E-mail info@ntis.gov
Web site http://www.ntis.gov/support/ordernowabout.htm

Reports are available to DOE employees, DOE contractors, Energy Technology Data Exchange (ETDE) representatives, and International Nuclear Information System (INIS) representatives from the following source.

Office of Scientific and Technical Information

P.O. Box 62

Oak Ridge, TN 37831

Telephone 865-576-8401

Fax 865-576-5728

E-mail reports@osti.gov

Web site http://www.osti.gov/contact.html

This report was prepared as an account of work sponsored by an agency of the United States Government. Neither the United States Government nor any agency thereof, nor any of their employees, makes any warranty, express or implied, or assumes any legal liability or responsibility for the accuracy, completeness, or usefulness of any information, apparatus, product, or process disclosed, or represents that its use would not infringe privately owned rights. Reference herein to any specific commercial product, process, or service by trade name, trademark, manufacturer, or otherwise, does not necessarily constitute or imply its endorsement, recommendation, or favoring by the United States Government or any agency thereof. The views and opinions of authors expressed herein do not necessarily state or reflect those of the United States Government or any agency thereof. 
ORNL/TM-2012/118

Energy and Transportation Science Division

PHENYLNAPHTHALENE AS A HEAT TRANSFER FLUID FOR CONCENTRATING SOLAR POWER: HIGH-TEMPERATURE STATIC EXPERIMENTS

J.R. Bell

R.A. Joseph III

J. McFarlane

A.L. Qualls

May 2012

Prepared by

OAK RIDGE NATIONAL LABORATORY

Oak Ridge, Tennessee 37831-6283

managed by

UT-BATTELLE, LLC

for the

U.S. DEPARTMENT OF ENERGY

under contract DE-AC05-00OR22725 



\section{CONTENTS}

\section{Page}

LIST OF FIGURES

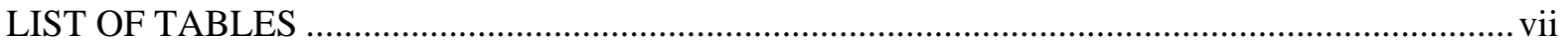

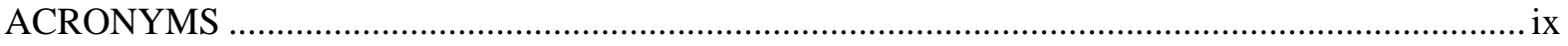

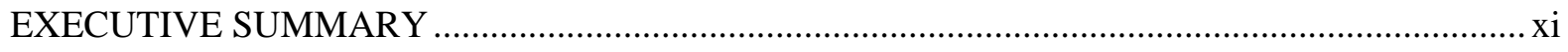

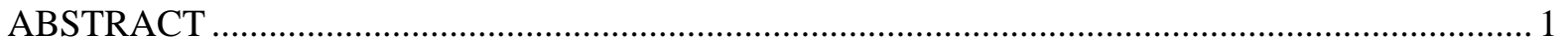

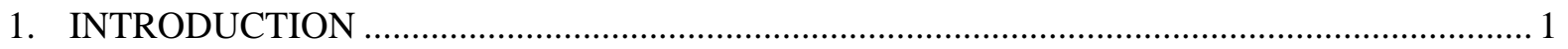

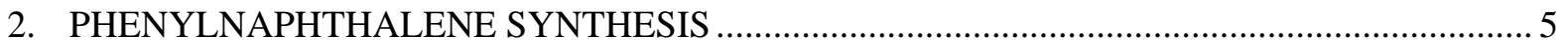

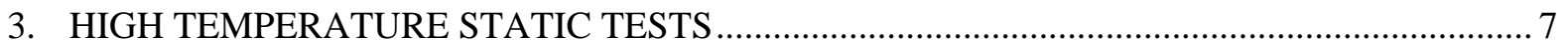

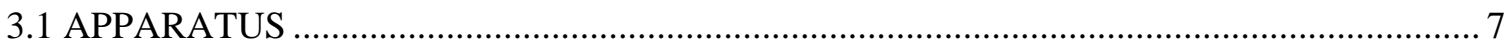

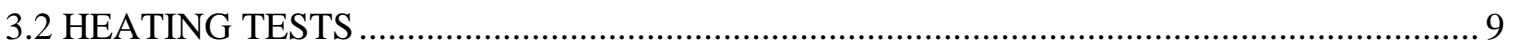

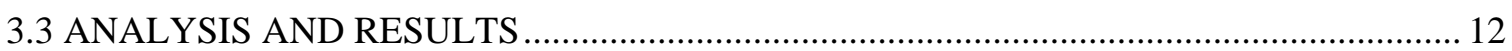

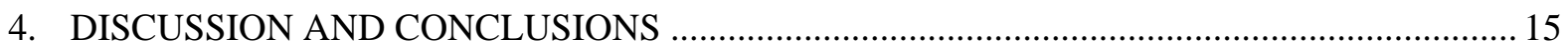

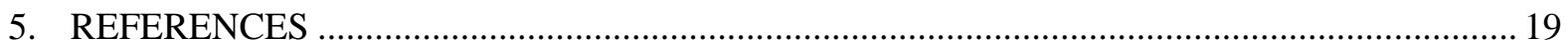

Appendix A: DETAILS ON THE HEATING EXPERIMENTS ................................................. A-1

Appendix B: QUANTIZATION OF GAS CHROMATOGRAPHIC ANALYSIS .......................... B-1 



\section{LIST OF FIGURES}

Figure

Page

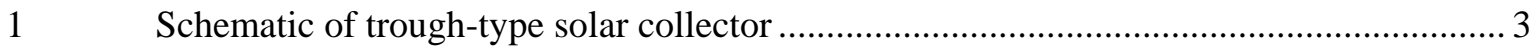

2 Arrhenius plot of vapor pressure as a function of reciprocal temperature ......................... 4

$3 \quad$ Calculated liquid viscosities as a function of temperature $(\mathrm{K})$...................................... 4

$4 \quad$ Schematic of 1-phenylnaphthalene synthesis ................................................................. 5

5 Synthesis of a several-hundred-mL batch of 1-phenylnapthalene in a chemical fume

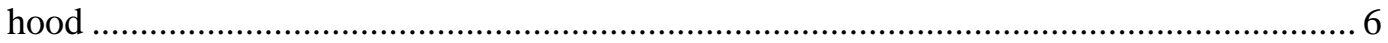

$6 \quad$ Furnace assembly showing sample tubes, copper block heater, and instrumented

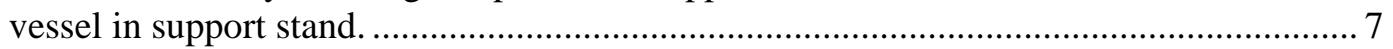

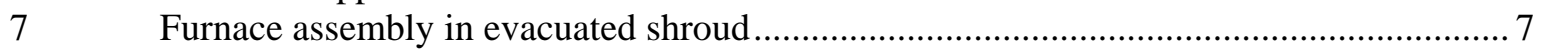

8 Capping of the fluid sample holder in the dry box under an argon atmosphere ................. 8

$9 \quad$ PID controller for heater element inserted into the copper block ................................... 9

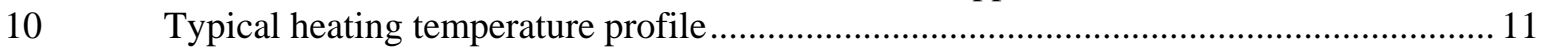

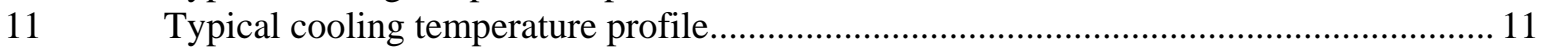

12 Steady-state temperature traces from the five recording thermocouple channels............. 11

13 Aluminum cell used for ramping experiments, showing two sample holders and

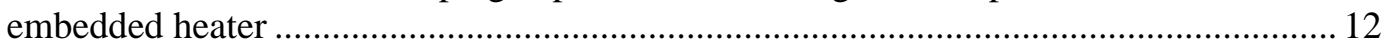

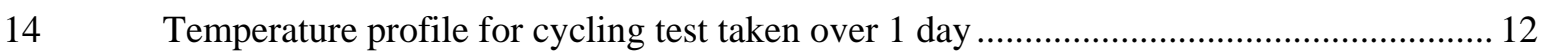

$15 \quad$ GC traces for heated 1-phenylnaphthalene ................................................................... 13

16 Data from the GC-MSD showing the ion spectrum of 1-phenylnapthalene captured at $5.54 \mathrm{~min}$

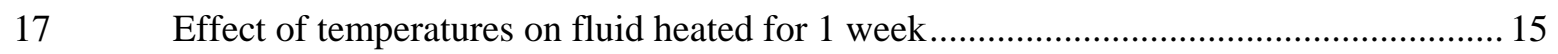

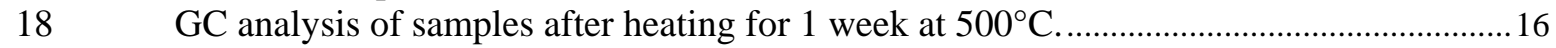

19 Fragmentation mechanism for 1-phenylnaphthalene at temperatures above $500^{\circ} \mathrm{C} \ldots \ldots . . .17$ 



\section{LIST OF TABLES}

\section{Table}

Page

1 Survey of the thermal properties of heat transfer fluids used in solar applications ............ 2

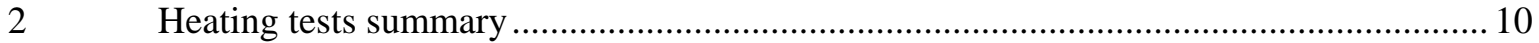

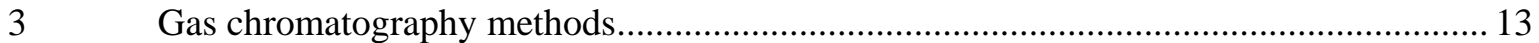





\section{ACRONYMS}

$\begin{array}{ll}\text { CSP } & \text { Concentrating solar power } \\ \text { FID } & \text { Flame ionization detector } \\ \text { GC } & \text { Gas chromatograph } \\ \text { ID } & \text { Inner diameter } \\ \text { MSD } & \text { Mass selective detector } \\ \text { ORNL } & \text { Oak Ridge National Laboratory } \\ \text { PID } & \text { Proportional-integral-derivative } \\ \text { TEMPO } & \text { 2,2,6,6,-tetramethylpiperidinyl-1-oxyl } \\ \text { UHP } & \text { Ultra high purity } \\ \text { USDOE } & \text { United States Department of Energy }\end{array}$





\section{ACKNOWLEDGMENTS}

The authors would like to thank Jason Braden, Bob Sitterson, and particularly Andy Christopher for the fabrication work they did for this project.

This research was sponsored by the US Department of Energy Office of Efficiency and Renewable Energy, with funding from the American Recovery and Reinvestment Act. Oak Ridge National Laboratory (ORNL) is managed by UT-Battelle, LLC for the U.S. Department of Energy under contract DE-AC05-00OR22725. 



\section{EXECUTIVE SUMMARY}

Greater thermodynamic efficiency is needed to improve the feasibility of concentrating solar power (CSP) devices. This will largely depend on equipment and fluids that can run at higher temperatures than existing power plants - currently up to $400^{\circ} \mathrm{C}$. This project tested substituted polyaromatic hydrocarbons as heat transfer fluids for solar power, which have not yet been considered because of the scarcity of relevant thermophysical data. The project involved the synthesis of 1-phenylnaphthalane synthetic oil, gathering data on thermodynamic and physical properties, studying thermal stability, and testing performance in pressurized loops. In particular, this report discusses results of static heating tests on small samples up to $500^{\circ} \mathrm{C}$.

The samples being tested were synthesized at Oak Ridge National Laboratory (ORNL) using a Suzuki coupling mechanism. High yields were obtained with sample purities reaching $99 \%$ as determined by nuclear magnetic resonance (NMR) and gas chromatography (GC). Small amounts, on the order of $1 \mathrm{~mL}$, were subjected to heating in stainless steel vessels from 400 to $500^{\circ} \mathrm{C}$, usually over the period of one week. Coupons representing structural materials that may be found in the trough-type collectors of a CSP plant were introduced. Although most of the tests were carried out with 1-phenylnaphthalene, fluoranthene, TEMPO, and selected ionic liquids were also heated. Ramping tests were carried out on samples of synthetic oil between 290 and $450^{\circ} \mathrm{C}$, typical of the thermal cycle in a CSP operation. Thermal data were taken on the heating experiments, and samples were analyzed by GC after heating to determine if breakdown products were present.

GC analysis indicated that the synthetic substituted naphthalene oils did not show any chemical change up to $400^{\circ} \mathrm{C}$. At steady heating for 1 week at $450^{\circ} \mathrm{C}$, some isomerization to 2-phenylnaphthalene was observed, but this was not accompanied by breakdown products. There was evidence of sample conversion to fluoranthene and other products at $500^{\circ} \mathrm{C}$; however, the rate of conversion was slow and the system did not appear to have reached thermodynamic equilibrium. Tests are planned to carry out the heating for at least a couple of months to determine the equilibrium condition. The samples did not appear to decompose under thermal cycling, and this will be tested further in a high temperature loop at ORNL. Analysis by pyrolysis GC and light scattering is also planned.

Although the synthetic oil can be produced by the Suzuki coupling mechanism, the cost is estimated as about $\$ 950 \cdot \mathrm{L}^{-1}$, close to the $\$ 700 \cdot \mathrm{kg}^{-1}$ estimate based on the commodity cost of cumene, a comparable molecule. Although 1-phenylnaphthalene may be isolated during the refining of petroleum, direct synthesis may allow better quality control. Ways of reducing the cost have been identified for investigation. These include reuse of the platinum catalyst and choice of less expensive starting materials, for instance using an iodonaphthalene rather than the brominated material.

In summary, it appears as if 1-phenylnaphthalene may be a candidate heat transfer fluid up to $450^{\circ} \mathrm{C}$, if not above, and could be used to increase the thermodynamic efficiency of a high temperature solar collector for CSP applications. 



\begin{abstract}
Concentrating solar power (CSP) may be an alternative to generating electricity from fossil fuels; however, greater thermodynamic efficiency is needed to improve the economics of CSP operation. One way of achieving improved efficiency is to operate the CSP loop at higher temperatures than the current maximum of about $400^{\circ} \mathrm{C}$. ORNL has been investigating a synthetic polyaromatic oil for use in a trough type CSP collector, to temperatures up to $500^{\circ} \mathrm{C}$. The oil was chosen because of its thermal stability and calculated low vapor and critical pressures. The oil has been synthesized using a Suzuki coupling mechanism and has been tested in static heating experiments. Analysis has been conducted on the oil after heating and suggests that there may be some isomerization taking place at $450^{\circ} \mathrm{C}$, but the fluid appears to remain stable above that temperature. Tests were conducted over one week and further tests are planned to investigate stabilities after heating for months and in flow configurations. Thermochemical data and thermophysical predictions indicate that substituted polyaromatic hydrocarbons may be useful for applications that run at higher temperatures than possible with commercial fluids such as Therminol-VP1 [1].
\end{abstract}

\title{
1. INTRODUCTION
}

Recent analysis has indicated that concentrating solar power installations need to operate at higher temperatures than currently typical to improve the economics in comparison with other alternative technologies [2]. CSP has a benefit of inherent thermal energy storage, but this requires efficient and reversible heat transfer between the storage fluid and the power cycle. In this paper, the possibility of using a polyaromatic hydrocarbon as a heat transfer fluid for a trough design solar collector has been explored. Low vapor pressure and resistance to thermal decomposition may make phenylnaphthalenes and similar polyaromatic hydrocarbons suitable as the heat transfer fluid in parabolic solar collectors. In particular, 1-phenylnaphthalene has an advantage over high temperature inorganic salts because it is a liquid at room temperature; however, its performance in a high temperature loop has not yet been demonstrated. Promising thermodynamic properties for these fluids have been estimated at high temperatures based on equation of state calculations and correlations for transport properties [3]. In this project the criteria that have been addressed are (i) the thermal stability of the fluid and (ii) the synthesis using a Suzuki coupling reaction.

A survey of heat transfer fluids for solar power generation is shown in Table 1. Key thermophysical parameters that dictate if the fluid can be used for certain applications include: boiling and melting points or liquid range, critical temperature and pressure, vapor pressure under the conditions of operation, thermal conductivity, viscosity, density, and heat capacity. Thermodynamic properties give the ranges of parameters over which the fluid will be able to transport heat effectively from the solar collector to the power cycle. Transport properties such as viscosity as well as density indicate the pumpability of the fluid. Heat capacity and thermal conductivity indicate the ability of the fluid to capture and release heat in the collector and downstream heat exchangers. Another factor is the range of thermal stability of the fluids. Commonly used fluids break down below $400^{\circ} \mathrm{C}$, releasing $\mathrm{H}_{2}$ and organic vapors. The high thermal conductivity of $\mathrm{H}_{2}$ and its ability to pass through metal pipes causes even small amounts of $\mathrm{H}_{2}$ to enter the vacuum tube surrounding the collector, Fig. 1, thus impairing the insulating value of the shroud and reducing the collection efficiency. Loops are pressurized to prevent fluid boiling, and so aging and hydrogen embrittlement may cause stress corrosion cracking after decades of use [4]. For heat transfer 
fluids the maximum operating temperature relates to the temperature above which appreciable thermal decomposition can occur. Because the operating range varies, thermodynamic data in Table 1 is given for a point within the range of applicability, and so is not necessarily the same for all fluids in the table. The currently used organic fluid that achieves the highest temperature is a mixture of biphenyl and diphenyl oxides, going by trade names Dowtherm A or Therminol VPI. For these fluids, properties are given both for the standard temperature of $600 \mathrm{~K}$ and for the maximum temperature of $678 \mathrm{~K}$ to assist with comparisons. The last entry on the table, 1-phenylnaphthalene, is the fluid that is under investigation in this report.

Table 1. Survey of the thermal properties of heat transfer fluids used in solar applications.*

\begin{tabular}{|c|c|c|c|c|c|c|c|}
\hline $\begin{array}{l}\text { Compound or } \\
\text { mixture }\end{array}$ & $\begin{array}{l}T_{m} \\
T_{b} \\
\mathbf{K}\end{array}$ & $\begin{array}{c}C_{p} \\
\mathrm{~kJ} \cdot \mathrm{kg}^{-1} \mathrm{~K}^{-1}\end{array}$ & $\begin{array}{c}\text { Liquid } \\
\rho \\
\mathrm{kg} \cdot \mathrm{m}^{-3}\end{array}$ & $\begin{array}{c}T_{c}(\mathrm{~K}) \\
P_{c} \text { (bar) }\end{array}$ & $\begin{array}{c}\text { Vapor } \\
\text { Press. } \\
\text { bar }\end{array}$ & $\begin{array}{l}\text { Liquid } \lambda \\
\mathbf{W} \cdot \mathbf{m}^{-1} \cdot \mathbf{K}^{-1}\end{array}$ & $\begin{array}{l}\text { Liquid } \\
\qquad \begin{array}{c}v \\
\mathrm{mPa} \cdot \mathrm{s}\end{array}\end{array}$ \\
\hline $\begin{array}{l}\text { Dowtherm A [5] } \\
\text { Therminol VP1[1] } \\
\text { Biphenyl \& } \\
\text { diphenyl oxides } \\
\text { @ } 600 \mathrm{~K} \\
\text { @ } 678 \mathrm{~K} \text { (Max) }\end{array}$ & $\begin{array}{l}285.2 \\
530.2\end{array}$ & $\begin{array}{c}2.39 \\
2.725\end{array}$ & $\begin{array}{c}788 \\
672.5\end{array}$ & $\begin{array}{c}771 \pm 1 \\
32.2 \pm 0.9\end{array}$ & $\begin{array}{c}3.8 \\
11.32\end{array}$ & $\begin{array}{l}0.0912 \\
0.0771\end{array}$ & $\begin{array}{l}0.20 \\
0.12\end{array}$ \\
\hline $\begin{array}{l}\text { Xceltherm } 600-\mathrm{C}_{20} \\
\text { paraffin oil [6] } \\
\text { @ } 588.8 \mathrm{~K}\end{array}$ & $\begin{array}{c}\boldsymbol{T}_{\boldsymbol{b}} \\
\text { range } \\
574- \\
741\end{array}$ & 3.001 & 672.36 & $\begin{array}{l}768 \\
10.7\end{array}$ & 0.2499 & 0.1122 & 0.252 \\
\hline $\begin{array}{l}\mathrm{H}_{2} \mathrm{O}[7] \\
@ 563 \mathrm{~K}, 7.5 \mathrm{MPa}\end{array}$ & $\begin{array}{c}273.1 \\
5 \\
373.1 \\
5\end{array}$ & 5.5 & 732 & $\begin{array}{l}646.95 \\
220.64\end{array}$ & $\begin{array}{l}\text { Super- } \\
\text { heated }\end{array}$ & 0.56 & 0.13 \\
\hline $\begin{array}{l}\text { Biphenyl [8-11] } \\
\text { @ } 500 \mathrm{~K}\end{array}$ & $\begin{array}{l}342 \\
559\end{array}$ & 2.03 & 869 & $\begin{array}{l}773 \pm 3 \\
33.8 \pm 1\end{array}$ & 0.531 & 0.118 & 0.32 \\
\hline $\begin{array}{l}p \text {-Terphenyl [8-12] } \\
\text { @ 500 K }\end{array}$ & $\begin{array}{l}485 \\
623 \\
\end{array}$ & 1.98 & 947 & $\begin{array}{c}908+10 \\
29.9 \pm 6 \\
\end{array}$ & 0.0199 & 0.135 & 0.73 \\
\hline $\begin{array}{l}\text { Therminol } 66 \text { [13] } \\
\text { Mix of } \\
\text { hydrogenated } \\
\text { terphenyls } \\
\text { @ } 600 \mathrm{~K} \\
618 \mathrm{~K} \text { (Max) }\end{array}$ & $\begin{array}{l}266 \\
632\end{array}$ & 2.67 & 786 & $\begin{array}{l}842 \\
24.3\end{array}$ & 0.542 & 0.0911 & 0.359 \\
\hline $\begin{array}{l}1- \\
\text { phenylnaphthalene } \\
\text { [3] } \\
\text { @ 600K }\end{array}$ & $\begin{array}{c}\boldsymbol{T}_{\boldsymbol{m}} \\
\text { range } \\
297- \\
318 \\
598\end{array}$ & 2.6 & 849 & $\begin{array}{l}818 \\
7.1\end{array}$ & 0.820 & 0.077 & 0.11 \\
\hline
\end{tabular}

* $T_{m}$ is melting temperature and $T_{b}$ is normal boiling point, $C_{p}$ is liquid heat capacity at contact pressure. $\rho$ is density. $T_{c}$ and $P_{c}$ are the critical temperature and pressure respectively. $\lambda$ is the liquid thermal conductivity and $v$ is the liquid kinematic viscosity. 
Polyaromatic hydrocarbons are problematic chemicals in refined petroleum and must be removed from diesel fuels because they survive combustion conditions in the compression ignition engine and can serve as sites for nucleation of soot particles. Preliminary investigations of these fluids have shown that they may be stable to temperatures above $500^{\circ} \mathrm{C}$, have good thermal characteristics, and do not react with the vessels in which they are contained [3]. For some of these fluids, thermophysical data is available. Vapor pressure, which appears to be much lower than for other organic fluids, is shown in an Arrhenius plot, in Fig. 2. The graph also shows the operating temperatures of 300 and $500^{\circ} \mathrm{C}$ as an aid to interpreting the inverse temperature on the abscissa. Also shown on the plot are the vapor pressures of 2-phenylnaphthalene and fluoranthene, which may be less desirable as heat transfer fluids for concentrating solar power as they are solids at room temperature. However, these compounds may be more stable than 1-phenylnaphthalene at higher temperatures and their vapor pressures are slightly lower. Fig. 3 shows the calculated viscosity of 1-phenylnapthalene based on equation of state correlations. These data are not available at high temperatures and the error bars indicate the deviation arising from using the results of different empirical relationships. The uncertainty in these results represent a risk factor in using the polyaromatic hydrocarbon as a heat transfer fluid above $400^{\circ} \mathrm{C}$, however the results of the correlation are not dissimilar from other organic fluids.

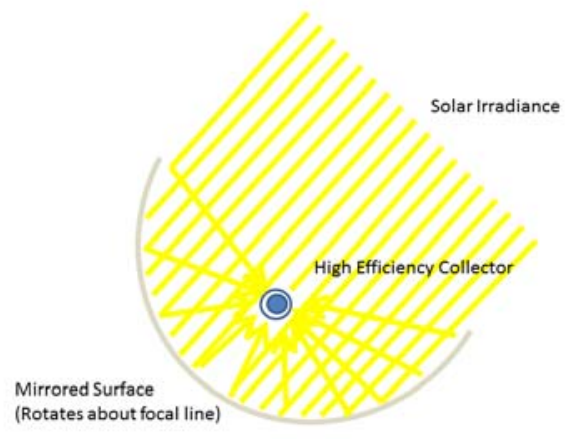

Fig. 1. Schematic of trough-type solar collector

Before consideration for use in power plant operations, the fluids need to be evaluated with respect to a number of technical criteria. These include: (1) optimizing the chemistry and thermophysical properties of candidate heat transfer fluids for repetitive cycling to high temperatures; (2) testing the performance of the heat transfer fluids in an instrumented flow loop; and (3) testing of performance in a pilot-scale concentrating solar loop at facilities of Cool Energy Inc. This report covers progress on the first of these tasks. The primary benefit of using the phenylnaphthalenes will be the ability to operate thermal storage systems and small scale power conversion equipment at higher temperatures than the current $400^{\circ} \mathrm{C}$ maximum, which will increase conversion efficiency. Higher temperature operation, however, often occurs at the expense of higher capital costs and shorter operational lifetimes. These new fluids, if successful, will allow higher temperature operation at acceptable pressures without accelerated material interactions or fluid degradation, and provide an option for parabolic and Fresnel solar collectors for power generation at temperatures up to $500^{\circ} \mathrm{C}$.

The first phase of the project focused on the chemistry of the proposed high temperature heat transfer fluids. A combination of electronic structure calculations, physical property measurements, static, and 
slow ramping high temperature tests were used to evaluate and optimize the structure of the heat transfer fluids for thermal stability.

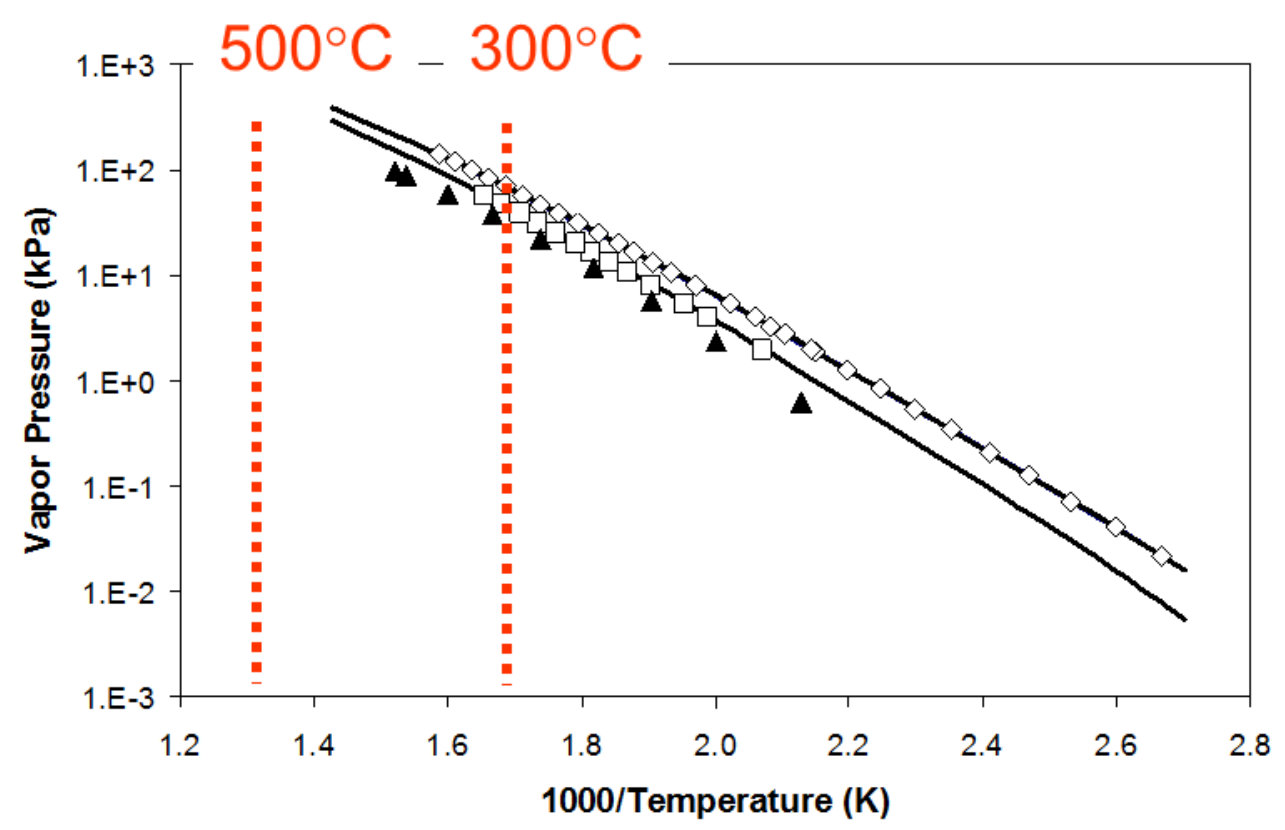

Fig. 2. Arrhenius plot of vapor pressure as a function of reciprocal temperature. Symbols on the plot refer to experimental data (1-phenylnapthalene, $\diamond, 2$-phenylnaphthalene, $\square$, and fluoranthene, $\mathbf{\Lambda}$. The solid lines are Wagner fits to these data. 


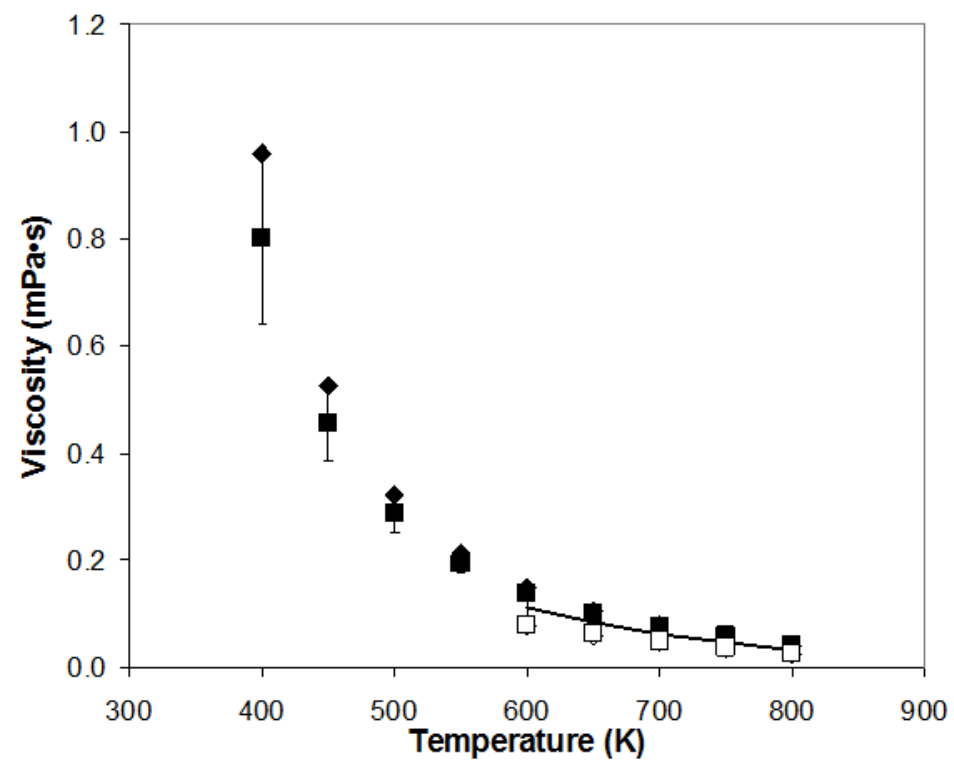

Fig. 3. Calculated liquid viscosities as a function of temperature (K). Different symbols correspond to different correlations for 1phenylnaphthalene, ^, and 2-phenylnaphthalene, $\mathbf{\square}, \square$. 


\section{PHENYLNAPHTHALENE SYNTHESIS}

Although the fluids under consideration may be readily available as the byproducts of clean-diesel refining $[14,15]$, for the purposes of this work a synthetic route was chosen to ensure purity of the fluid being tested. 1-phenylnaphthalene was synthesized by a modified Suzuki-Miyaura coupling reaction, Fig 4. 1-Bromonaphthalene (1.0 equiv) and phenylboronic acid (1.05 equiv.) were dissolved in npropanol. To this solution aqueous potassium carbonate (1.20 equiv) was added as a $3 \mathrm{M}$ solution. The catalyst, palladium acetate (0.003 equiv) and tri-(o-tolyl)phosphine (0.009 equiv), was added and the solution was brought to reflux for one hour. Water was added to the reaction, the phases were separated, and the aqueous phase was extracted three times with diethyl ether. Combined organic extracts were washed with brine, dried over magnesium sulfate, and the solvent was removed under reduced pressure. The brown product was then passed through a short silica plug to remove palladium impurities. The final product was purified by distillation. The colorless oil was obtained in 99\% purity by GC, and in 95\% isolated yield.

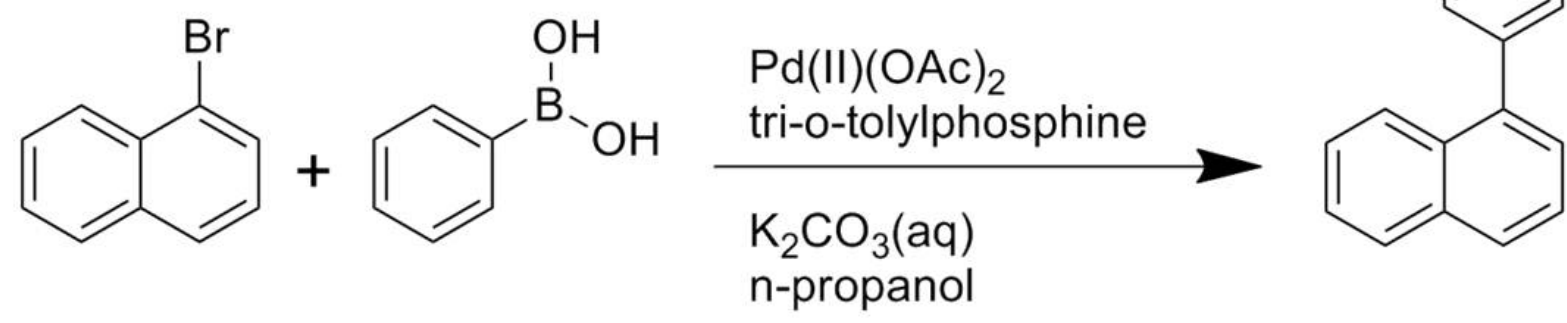

Fig. 4. Schematic of 1-phenylnaphthalene synthesis

Synthesis of the phenylnaphthalene was scaled up to produce several hundred $\mathrm{mL}$ at a time in a $3 \mathrm{~L}$ round bottomed flask, Fig 5 . The purification for each batch was done using rotary evaporation to remove the solvent, which can be recycled. Vacuum distillation was used to further purify the product, leaving only a trace of 2-phenylnapthalene,because it has a higher boiling point than the 1phenylnaphthalene. 


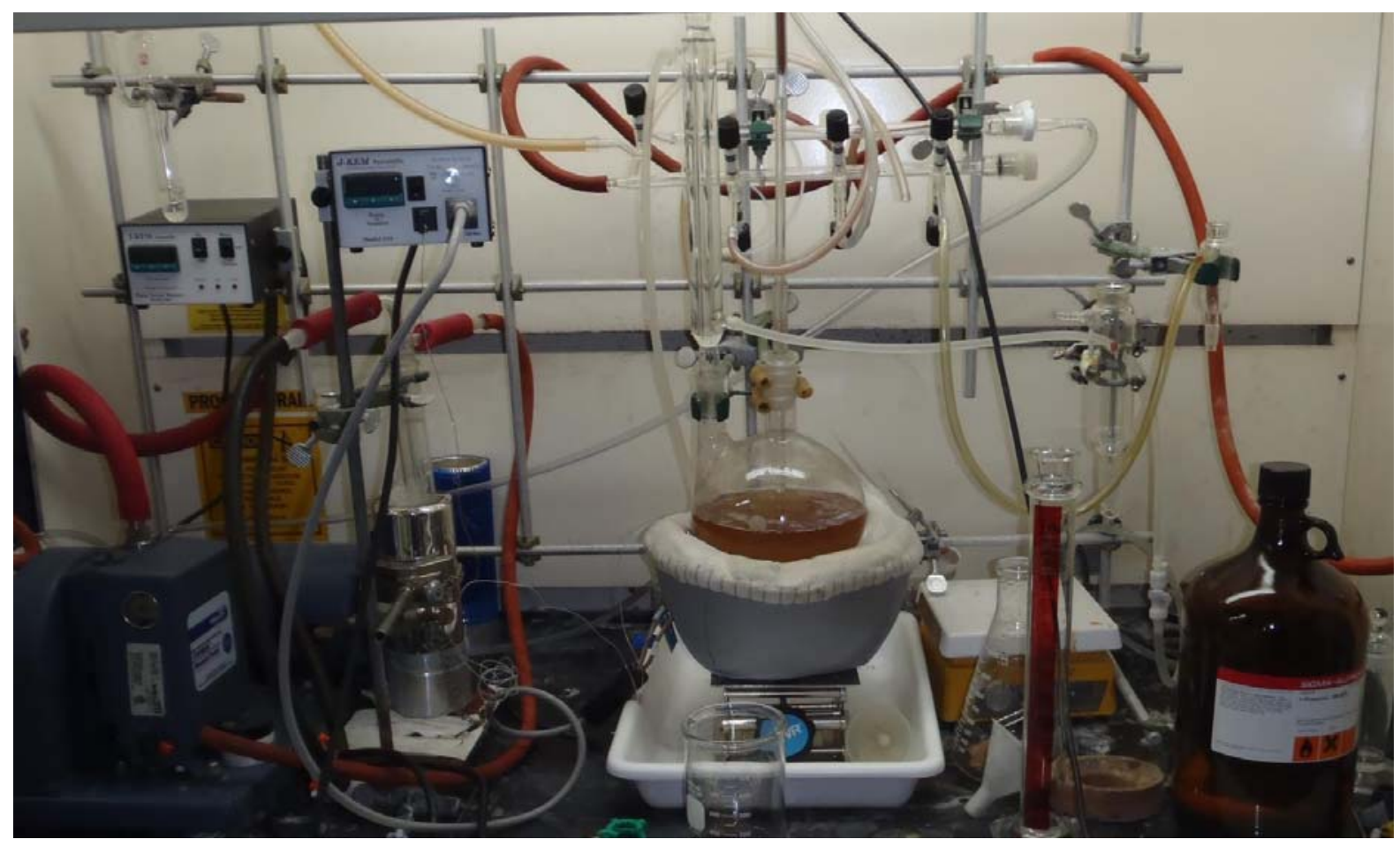

Fig. 5. Synthesis of a several hundred $\mathrm{mL}$ batch of 1-phenylnapthalene in a chemical fume hood. 


\section{HIGH TEMPERATURE STATIC TESTS}

\subsection{APPARATUS}

The thermal stability of 1-phenylnapththalene, a high-temperature thermal energy storage fluid, was tested at temperatures up to $525^{\circ} \mathrm{C}$ in contact with structural metal samples. Testing took place under static conditions in sealed capsules. The samples were held in thick-walled 316 stainless steel 3/8” outer diameter tubes that were initially sealed with Swagelok compression fittings on one end and a stainless steel stopcock-type valve on the other end. The capsules ranged from 4 to $7 \mathrm{~mL}$ in size and were partially filled with the synthetic oil to be tested, Fig. 6 . Because of sample leakage at high temperatures, these fittings were replaced with welds on the bottom and by flare fittings on the top. The heating assembly was enclosed in an evacuated shroud to minimize thermal losses from convection, Fig.7.

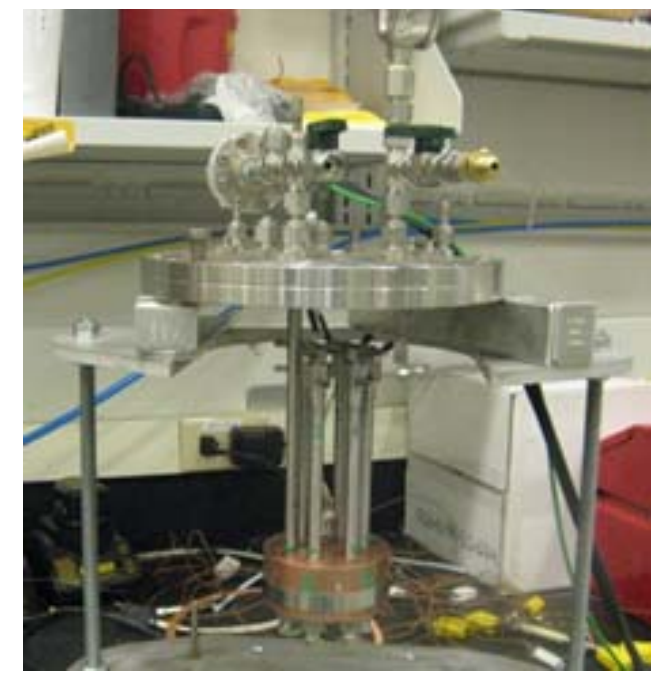

Fig. 6. Furnace assembly showing sample tubes, copper block heater, and instrumented vessel in support stand.

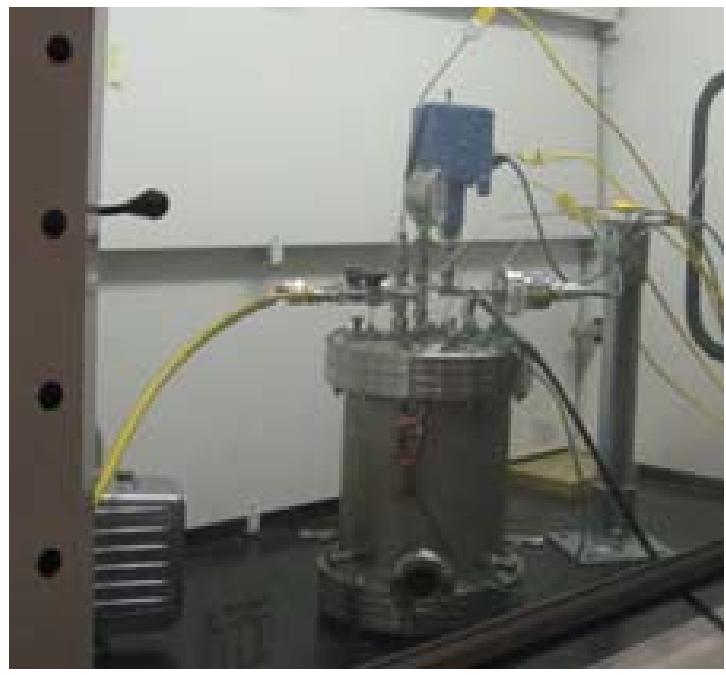

Fig. 7. Furnace assembly in evacuated shroud. The shroud could also be pressurized with gas to increase convective heat transfer.

Because of concerns about thermal degradation and pressure increases from the production of $\mathrm{H}_{2}$ or other volatile compounds, Reaction 1, potential pressure increases were calculated as part of the safety assessment conducted prior to the testing. The internal volume of the specimen holders was determined gravimetrically using fillings of deionized water, density of $1.00 \mathrm{~g} \cdot \mathrm{cm}^{-3}$. For additional security, the supplier (Swagelok) of the 316 stainless steel tubing provided a certification for a working pressure of $2500 \mathrm{psi}$ at an operating temperature of $600^{\circ} \mathrm{C}$.

$$
\mathrm{C}_{16} \mathrm{H}_{12} \longrightarrow \mathrm{C}_{16} \mathrm{H}_{10}+\mathrm{H}_{2}
$$

The specimen holders were filled with $1 \mathrm{~mL}$ of the sample fluid at room temperature in a glovebox with an inert argon cover gas, Fig 8. Small metal coupons ( $27 \mathrm{mg})$ were inserted into the fluid for compatibility testing. The cover gas pressure in the glove box was controlled at approximately $0.5 \mathrm{psi}$ above atmospheric pressure. The fluid fill, $1 \mathrm{~mL}$ by pipette, was chosen to prevent exceeding the allowable pressure assuming $2 \%$ fluid degradation by Reaction (1). After being sealed, the specimen holders were removed from the glovebox to be installed in the furnace. After thermal testing, the 
specimens were cooled, opened to check for gas release, and the fluid was sampled by gas chromatography (GC).

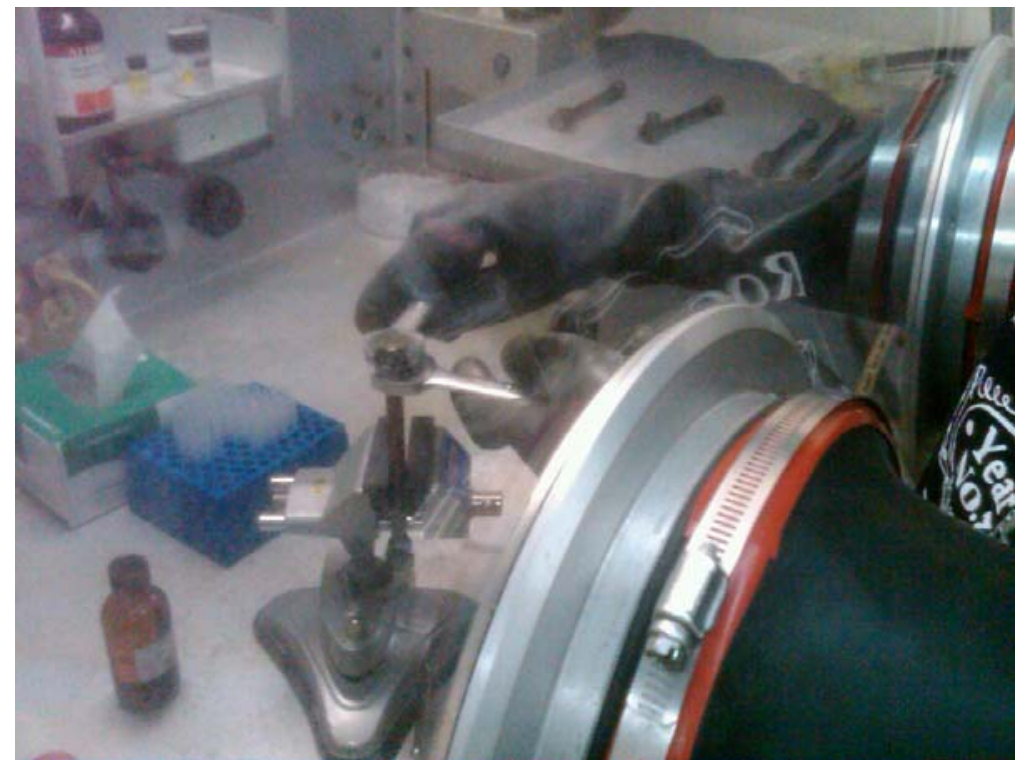

Fig. 8. Capping of the fluid sample holder in the dry box under an argon atmosphere.
The furnace was a small stainless steel vacuum chamber with an electrically heated copper block suspended from the top plate to minimize losses from conduction, Fig 6 . Thermocouples installed into small holes in the copper block monitored the block temperature directly. Wires from the thermocouples were attached to feedthroughs in the upper Conflat $^{\circledR}$ flange. The copper block was made of three pieces. Two outer pieces clamped to a main body and formed six mating vertical holes between the inner and outer sections. The specimen holders were held tightly in these holes by screws that passed through the outer pieces and threaded into the inner pieces to ensure good thermal contact. Five of the holes were usable for the sample holders previously described.

One of the six holes was occupied by a tube that penetrated the furnace upper plate. This exposed tube was used to monitor the temperature and pressure of a sample of fluid during the exposure. The tube was attached to a four-way cross, one side providing either vacuum or argon, to allow the creation of an inert atmosphere. A type $\mathrm{K}$ thermocouple extended directly into the fluid through the upper opening in the cross. One of the side ports was used as a pressure tap, attached to a 1000 psi pressure sensor (Omega). The temperature of the specimen was recorded throughout the experiment but was found to be unrepresentative of the other sample holders because of thermal cycling at a temperature of $365^{\circ} \mathrm{C}$, slightly above the boiling temperature of 1-phenylnaphthalene. The pressure reading was recorded manually to monitor for unexpected increases during the experiment. Although unexpected pressure or temperature increases were not observed during the experiments, this assembly served as an additional safety feature for furnace operation.

A cartridge heater fit into a hole in the center of the main part of the copper block. Electrical current was passed through the heater to generate heat that flowed radially into the copper block. An independent stand- alone controller built at ORNL was used to monitor the block temperature and control the current through the heater. The temperature was controlled manually using fixed current settings or in conjunction with a PID controller algorithm. The controller had an independent temperature cutoff circuit that terminates power to the heater if the input temperature exceeds a setpoint value.

The entire upper plate assembly was assembled outside of the vacuum chamber and inserted as a single unit and sealed at the top, Fig 7. Before sealing, a shroud of aluminum foil was wrapped around the assembly to minimize emissive losses. A small vacuum pump was used to maintain a vacuum on the vessel. The vacuum chamber and the pump operated entirely within a ventilation hood, but the controller was located outside of the hood to allow for easy access when the chamber was being heated. 


\subsection{HEATING TESTS}

The conditions for the thermal tests are summarized in Table 2, and further information is given in Appendix A. Five samples, besides the monitored vessel, could be heated at any one time. After filling the vessels and assembling the furnace, the chamber was evacuated to -29 in. $\mathrm{Hg}$ ( $0.03 \mathrm{bar}$ ) pressure using a direct drive mechanical pump. The heating tests involved ramping the sample to a predetermined temperature over a couple of hours and leaving it there for a week. The heating rate was set manually to be approximately $10-15^{\circ} \cdot \mathrm{min}^{-1}$, slowing down as the set point was approached. When the temperature was close to the set point, control was passed to a six-channel proportional-integral-derivative (PID) controller, Fig 9. Thermal cycling was not attempted in the first series of tests. Power was lost for a few hours on one of the runs (Test 7) necessitating re-establishment of high temperature conditions, but this was not thought to have changed the outcome of the experiment. From the second test onwards, control of the heater was established with the inner thermocouple closest to the heater. The temperature of the sample was estimated as the mean of the temperatures of the inner and outer thermocouples. When steady-state had been reached, the difference between the inner and outer blocks was about $14^{\circ} \mathrm{C}$.

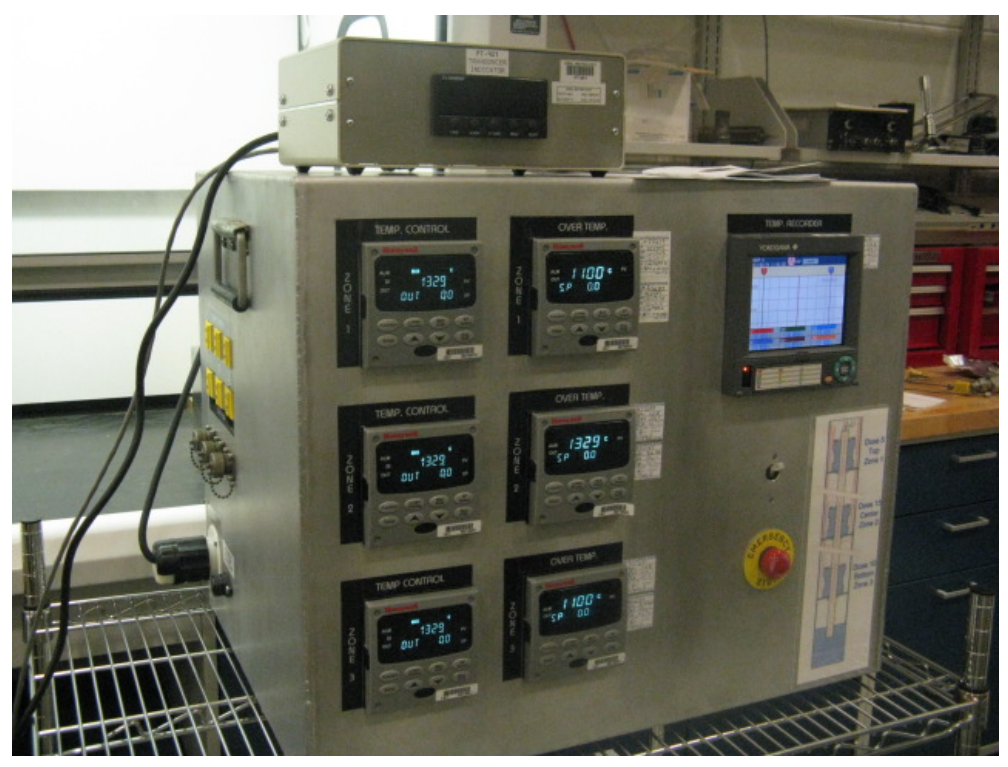

Fig. 9. PID controller for heater element inserted into the copper block. Channels were also used to monitor and record the temperatures in the inner and outer blocks. One channel was used for control, and three were used to monitor temperatures in the block.

Ten static heating tests of at least one week each were performed on 1-phenylnaphthalene, and mixtures of 1-phenylnaphthalene and minor components such as fluoranthene or 2,2,6,6,-tetramethylpiperidinyl-1oxy (TEMPO), Table 2. Two ionic liquids with bicyclic cations were prepared, 1-butyl-2,3trimethyleneimidazolium-bis(trifluoromethanesulfonyl)imide and 1-butyl-2,3-tetramethyleneimidazolium bis(trifluoromethylsulfonyl)imide, and tested as they had shown stabilities in thermogravimetic tests up to $475^{\circ} \mathrm{C} \dagger$.

† Private communication, Jason Bell, July 15, 2011. 
The high temperature organic fluid was found to escape compression fittings, and some of the earlier tests failed because of loss of sample during the run, as indicated by the notes in the table. Eventually, flare fittings torqued to $50 \mathrm{psi}$ were found to seal the best over a long experiment. The samples were heated to temperatures ranging from 282 to $536^{\circ} \mathrm{C}$, probing performance at temperatures beyond the range of commonly used heat transfer fluids such as Therminol VP-1. Some of the samples were heated in contact with coupons of materials that may be found in the heat transfer loop of a trough-type concentrating solar power plant [16]: carbon steel, brass, and DIN1.4541 stainless steel.

Table 2. Heating Tests Summary

\begin{tabular}{|c|c|c|c|c|c|}
\hline \multirow[b]{2}{*}{ Test Number } & \multirow[b]{2}{*}{ Fluid(s) } & \multirow[b]{2}{*}{ Notes } & \multicolumn{3}{|c|}{ Heating Details } \\
\hline & & & $\begin{array}{c}\text { Maximum } \\
\text { Temp }\left( \pm 4^{\circ} \mathrm{C}\right)\end{array}$ & $\begin{array}{c}\text { Duration } \\
( \pm 1 \mathrm{~h})\end{array}$ & Coupons \\
\hline 1 & $1-\mathrm{C}_{16} \mathrm{H}_{12}$ & Samples lost & 536 & 29 & no \\
\hline 2 & 1- $\mathrm{C}_{16} \mathrm{H}_{12}$ & Samples lost & 494 & 169 & no \\
\hline 3 & $1-\mathrm{C}_{16} \mathrm{H}_{12}$ & $\begin{array}{l}\text { Lost } 2 \text { of } 4 \\
\text { samples }\end{array}$ & 490 & 165 & no \\
\hline $4 a$ & 1- $\mathrm{C}_{16} \mathrm{H}_{12}$ & $\begin{array}{c}\text { Pressure } \\
\text { gauge failed }\end{array}$ & 482 & 2 & no \\
\hline $4 \mathrm{~b}$ & $1-\mathrm{C}_{16} \mathrm{H}_{12}$ & & 482 & 336 & no \\
\hline 5 & 1- $\mathrm{C}_{16} \mathrm{H}_{12}$ & & 536 & 337 & no \\
\hline 6 & $\begin{array}{l}\text { 1- } \mathrm{C}_{16} \mathrm{H}_{12} \text {, } \\
\text { ionic liquids }\end{array}$ & & 385 & 169 & yes \\
\hline 7 & 1- $\mathrm{C}_{16} \mathrm{H}_{12}$ & $\begin{array}{c}27 \text { h power } \\
\text { failure. } \\
\text { Samples lost }\end{array}$ & 454 & 240 & yes \\
\hline 8 & 1- $\mathrm{C}_{16} \mathrm{H}_{12}$ & Flare fittings & 446 & 175 & yes \\
\hline 9 & $1-\mathrm{C}_{16} \mathrm{H}_{12}$ & $\begin{array}{l}\text { SS \& C } \\
\text { coupons }\end{array}$ & 500 & 199 & yes \\
\hline 10 & $1-\mathrm{C}_{16} \mathrm{H}_{12}$ & & 500 & 171 & yes \\
\hline
\end{tabular}

Five temperatures were recorded every 2 s: two measurements in the inner block and two in the outer, and one in a sample vessel that protruded through the conflat flange at the top of the housing. A typical example of the data for heat up and cool down is shown below in Figs.10 and 11 for Run 10, showing an average between the inner and outer blocks - representative of the temperature of the sealed samples. Temperatures in the interim between heating and cooling were kept constant. They were very stable because of the PID control, to within $\pm 1^{\circ} \mathrm{C}$, Fig. 12, except for the protruding sample holder where refluxing of the fluid occurred. For the run shown in Fig. 12, the temperature at the sealed sample, the average of the inner and outer blocks, was about $530^{\circ} \mathrm{C}$ and much higher than the instrumented vessel. The error in this calculation was estimated to be no more than $\pm 5^{\circ} \mathrm{C}$ except during heat up, when the temperature of the outer block could lag that of the inner block by up to $50^{\circ} \mathrm{C}$. With the vessel evacuated, sample heat up took about $2 \mathrm{~h}$ in order to reach a stable plateau. The kink in the temperature profile during heating arose because control of the heater output was undertaken manually until very close to the desired temperature to prevent overshooting of the maximum value. The cool down took several hours and was usually done overnight. 


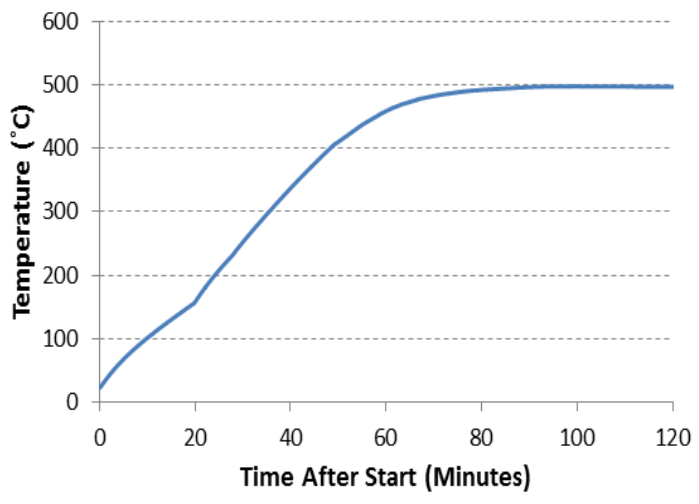

Fig. 10. Typical heating temperature profile.

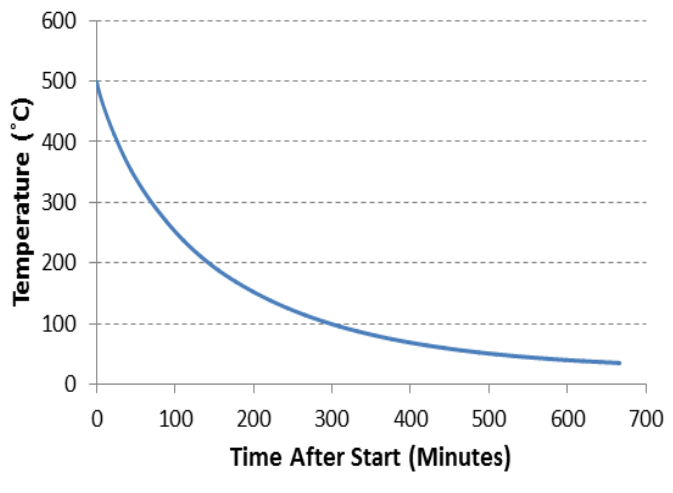

Fig. 11. Typical cooling temperature profile.

Similar temperature time graphs were recorded for all the runs. Because the appearance of these graphs is very similar, they are included in Appendix A for reference.

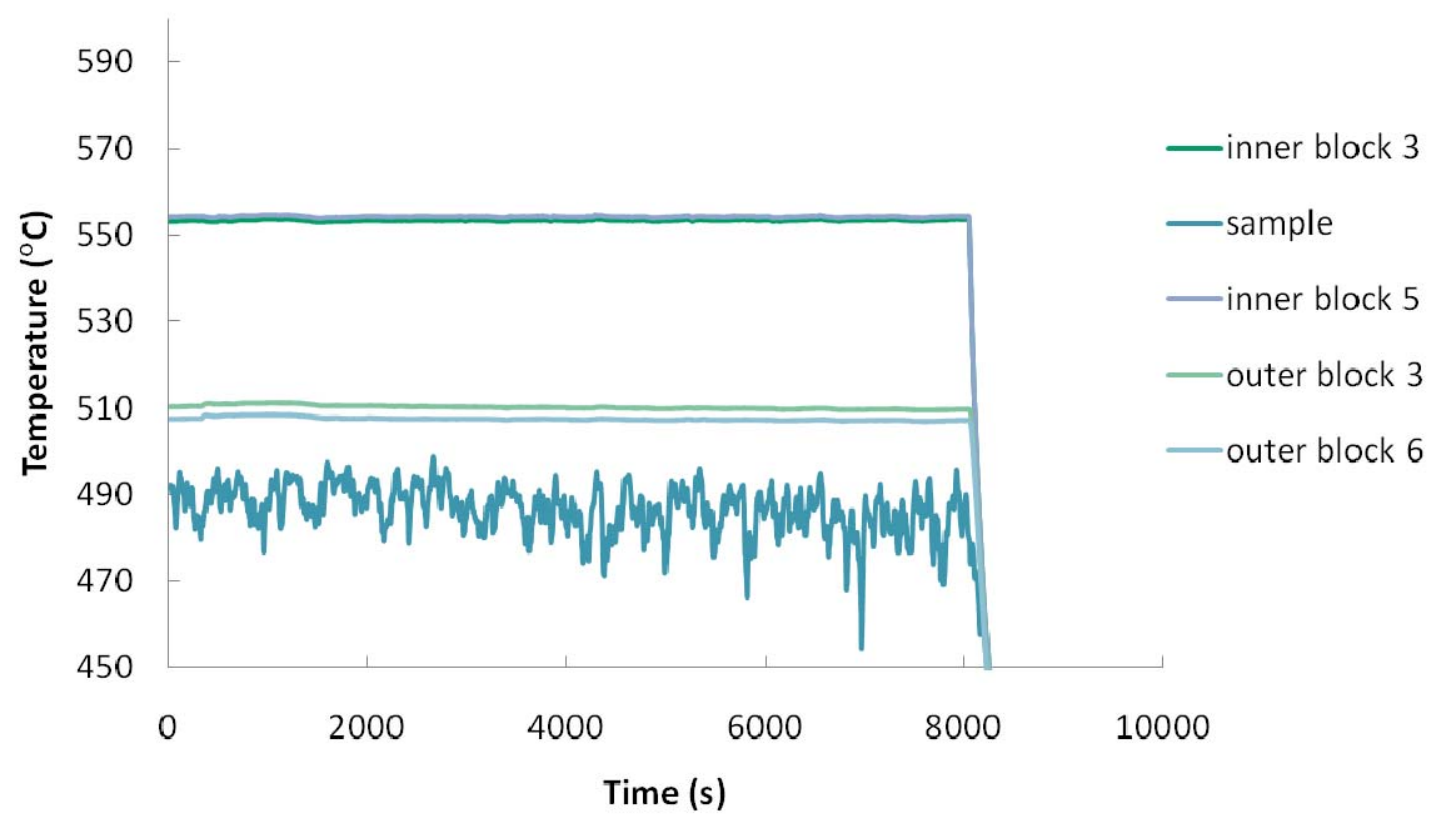

Fig. 12. Steady-state traces from the five recording thermocouple channels.

In addition to the heat-and-hold experiments, tests were also conducted by manually ramping the phenylnaphthalene fluid to simulate conditions that would be encountered in a trough CSP loop. These were to provide preliminary data prior to tests in a high-temperature flow loop. For the ramping experiments, a new vessel was designed from aluminum, Fig. 13. The vessel had much less mass, and could accommodate two sample holders. These tests were conducted with a flow of helium through the shroud of the chamber, to enhance heat up and cool down through convection. With a slight overpressure 
of helium (20 psig) corresponding to a flow rate of $8.5 \mathrm{~m}^{3} \cdot \mathrm{h}^{-1}$, a heat up of about $8 \mathrm{~min}$ and a cool down of 4 min were achieved between 290 and $450^{\circ} \mathrm{C}$.

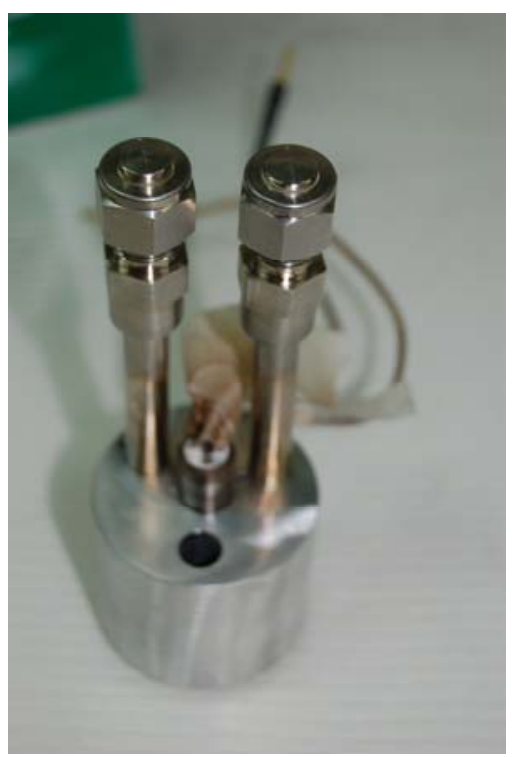

Fig. 13. Aluminum cell used for ramping experiments, showing two sample holders and embedded heater.

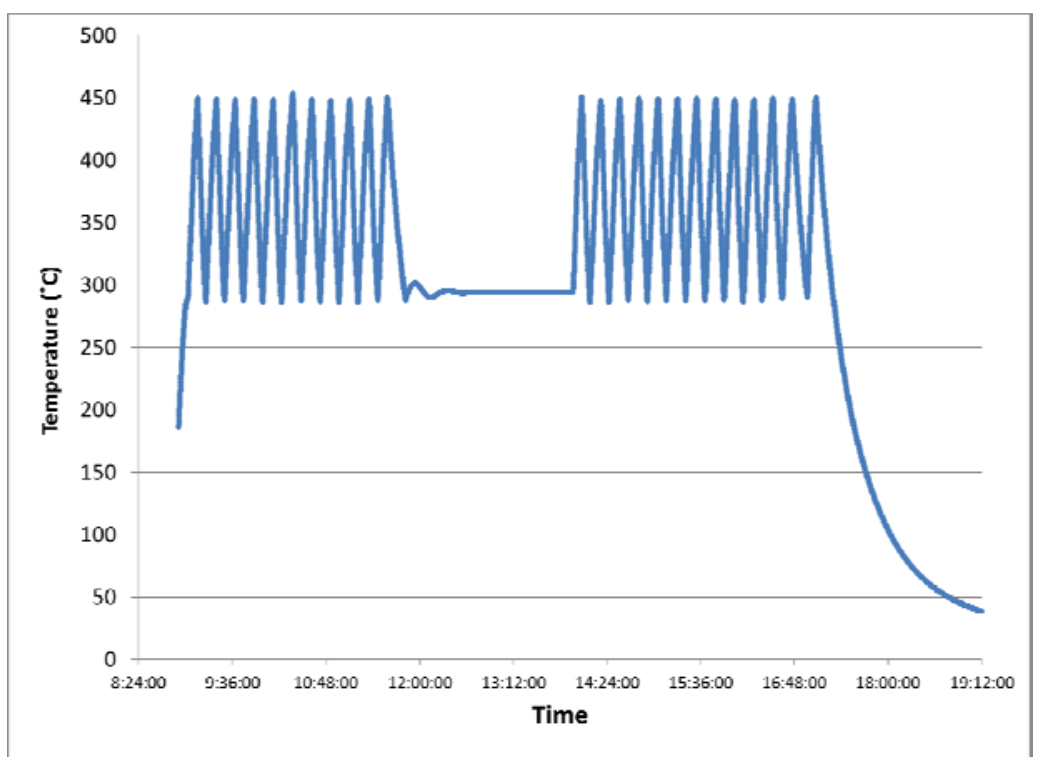

Fig. 14. Temperature profile for cycling test taken over 1 day.

\subsection{ANALYSIS AND RESULTS}

The analysis of the fluid after synthesis and before and after heating was done using Nuclear Magnetic Resonance Spectroscopy (NMR) and an HP 5890 GC, using either a Flame Ionization (FID) or a Mass Selective (MSD) detector. The proton Bruker Avance $400 \mathrm{MHz}$ NMR was useful in the detection of unreacted starting materials from the Suzuki coupling synthesis, but was less useful in distinguishing one isomer of phenylnaphthalene from another. The methods for the GC FID and the GC MSD are given in Table 3. The GCs were run using DB5 capillary columns with ultrahigh purity (UHP) Helium as a carrier gas (99.9999\%). Typical chromatograms from phenylnaphthalene are shown in Fig. 15 below. Retention times were assigned based on the use of calibration runs and by assignment using the ion fragmentation pattern from the GC-MSD. Polyaromatic hydrocarbons do not fragment in the mass spectrometer and have a large molecular ion, $\mathrm{M}^{+}$, thus making them easy to identify, Fig. 16. The uncertainty on quantification of the analysis is about $\pm 10 \%$, but is less for the FID than the MSD analysis. Details are given in Appendix B.

Unheated phenylnaphthalene has a large peak at a retention time of $5.5 \mathrm{~min}$. corresponding to 1phenylnaphthalene, with a small peak at about $6.2 \mathrm{~min}$ from the 2-phenylnaphthalene isomer, Fig. 15. Other peaks in the GC at 2.7 and 3.2 min come from unreacted starting material, such as naphthalene at $2.6 \mathrm{~min}$, and byproducts such as phenanthrene at $3.2 \mathrm{~min}$. As synthesized, the phenylnaphthalene has a purity of about $99 \%$. Some of the tests were done with commercial 1-phenylnaphthalene with $97 \%$ purity (Oakwood Products Inc., Lot E06C), but it did not make much difference to the results. After refluxing at $365^{\circ} \mathrm{C}$ for a week, the peaks from the impurities disappeared and only those from the two phenylnaphthalene compounds remained. When the sample was heated to $500^{\circ} \mathrm{C}$ for a week, further 
isomerization was observed to the 2-phenylnaphthalene, with growth in the peaks for naphthalene, phenanthrene, fluoranthene at $6.9 \mathrm{~min}$, and a variety of terphenyls $>7 \mathrm{~min}$.

Table 3. Gas Chromatography Methods

\begin{tabular}{l|ll}
\hline & $G C M S D$ & $G C$ FID \\
\hline Injector & $250^{\circ} \mathrm{C}$ & $150^{\circ} \mathrm{C}$ \\
& splitless & splitless \\
Oven Temperature Program & $150-270^{\circ} \mathrm{C} @ 15^{\circ} \cdot \mathrm{min}^{-1}$ & $150-270^{\circ} \mathrm{C} @ 15^{\circ} \cdot \mathrm{min}^{-1}$ \\
& Hold at $270^{\circ} \mathrm{C}$ for $3 \mathrm{~min}$ & Hold at $270^{\circ} \mathrm{C}$ for $3 \mathrm{~min}$ \\
Detector & $340^{\circ} \mathrm{C}$ & $340^{\circ} \mathrm{C}$ \\
Column & $30 \mathrm{~m}, 0.320 \mathrm{~mm} \mathrm{ID,} \mathrm{0.25 \mu m}$ & $30 \mathrm{~m}, 0.530 \mathrm{~mm} \mathrm{ID}, 0.5 \mu \mathrm{m}$ \\
Carrier gas & UHP helium @ 44 psig & UHP helium @ 40 psig \\
Solvent Delay & $2.2 \mathrm{~min}$ & Not applicable \\
\hline
\end{tabular}

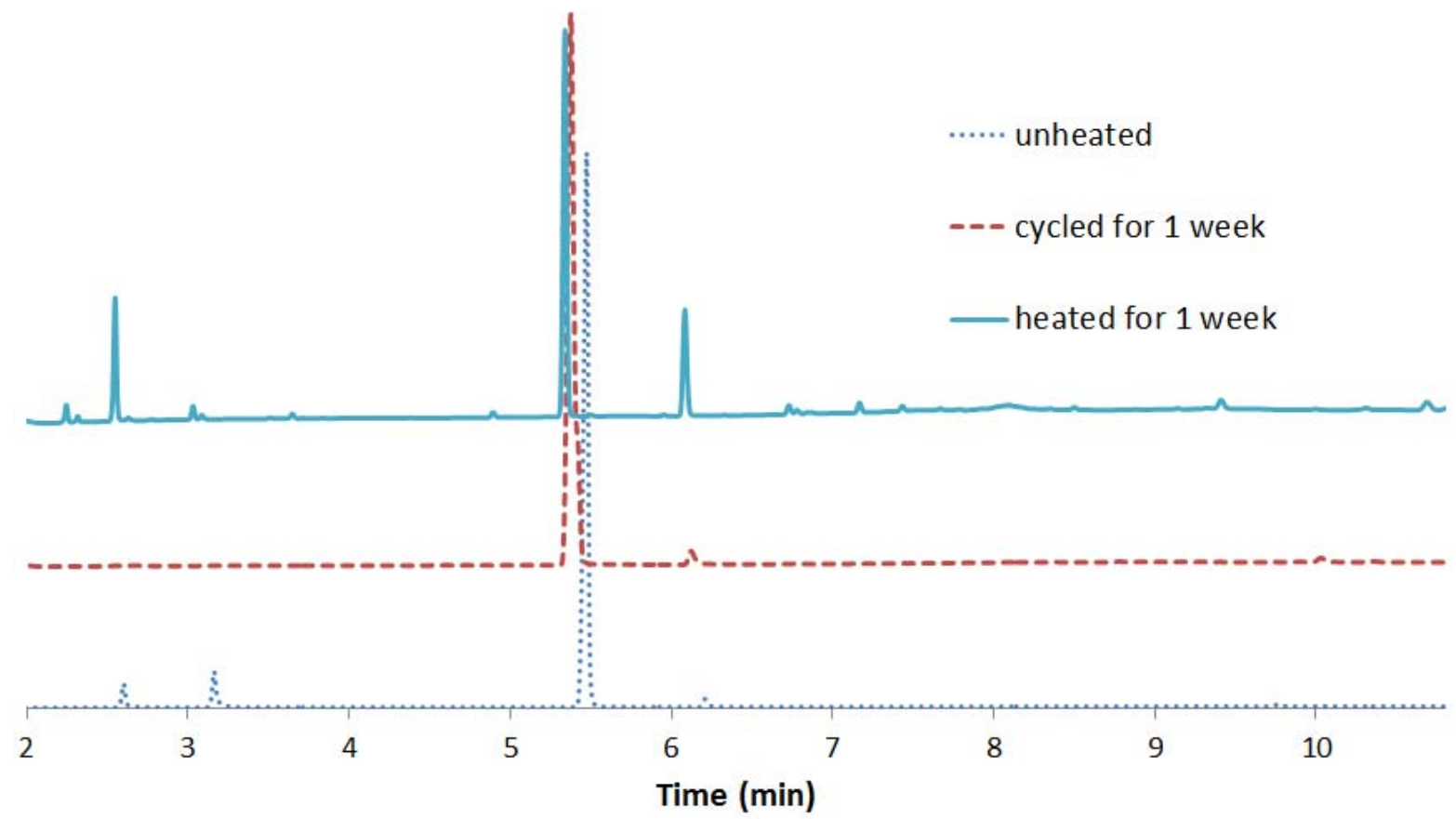

Fig. 15. GC traces for heated 1-phenylnaphthalene. 

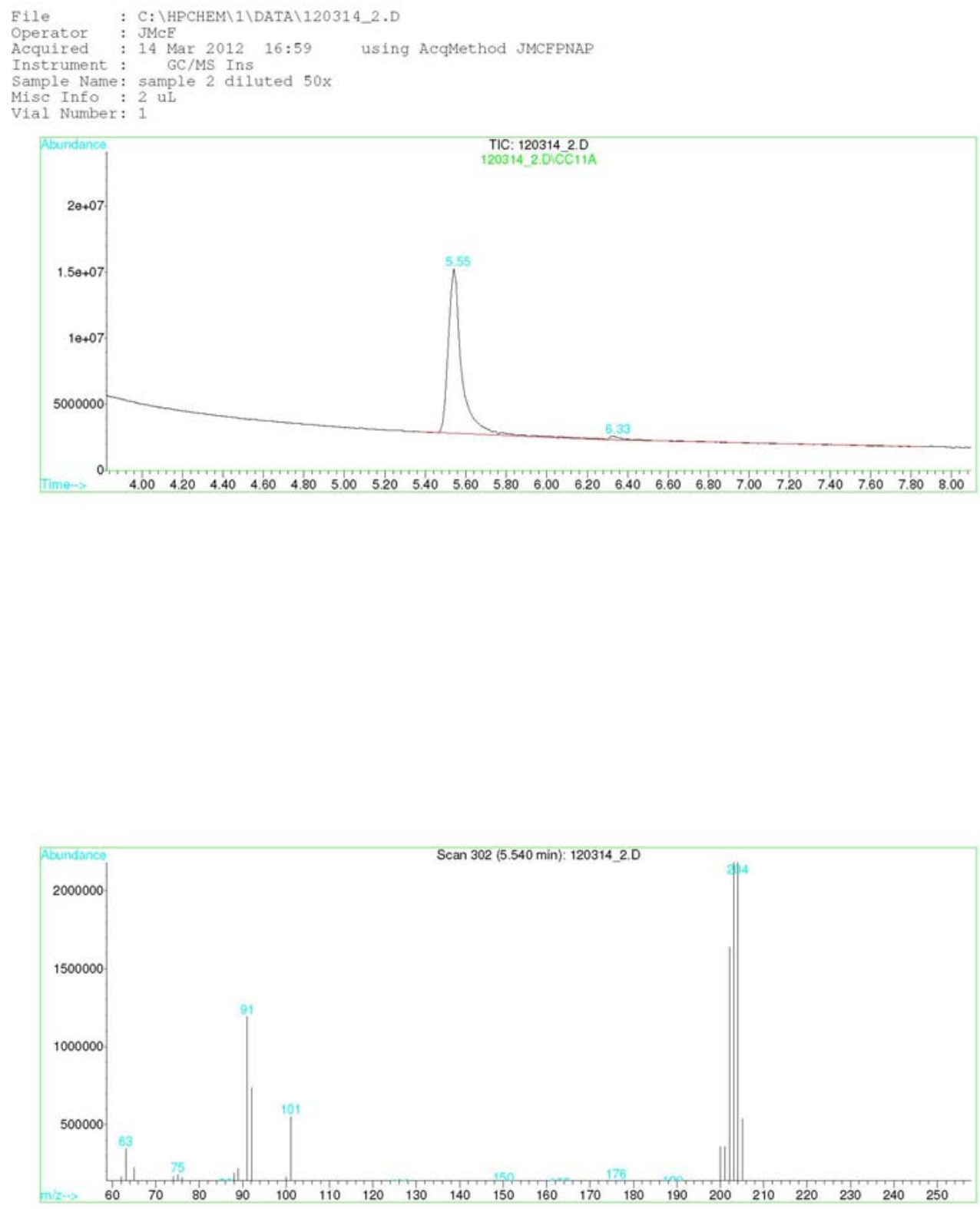

Fig. 16. Data from the GC-MSD showing the ion spectrum of 1-phenylnapthalene captured at $5.54 \mathrm{~min}$.

GC-MSD analyses were also carried out on 1-phenylnaphthalene samples that were repeatedly ramped from 290 to $450^{\circ} \mathrm{C}$ over the course of two days. One of the samples had about $100 \mathrm{mg} \mathrm{Fe}_{3} \mathrm{O}_{4}$ nanoparticles added to it to see if the magnetite would reduce the radical rearrangement from 1- to 2phenylnaphthalene. Samples were taken for GC-MSD analysis and no gas release was noticed when the holders were opened. The samples were discolored, but the GC-MSD indicated that they were 1phenylnaphthalene as synthesized. 


\section{DISCUSSION AND CONCLUSIONS}

A broad scope of heating experiments were conducted to ascertain the stability of the phenylnaphthalene fluid under a variety of conditions before introducing it into the high temperature loop for performance tests. Results from the parametric studies are summarized in Figs. 27 and 18.

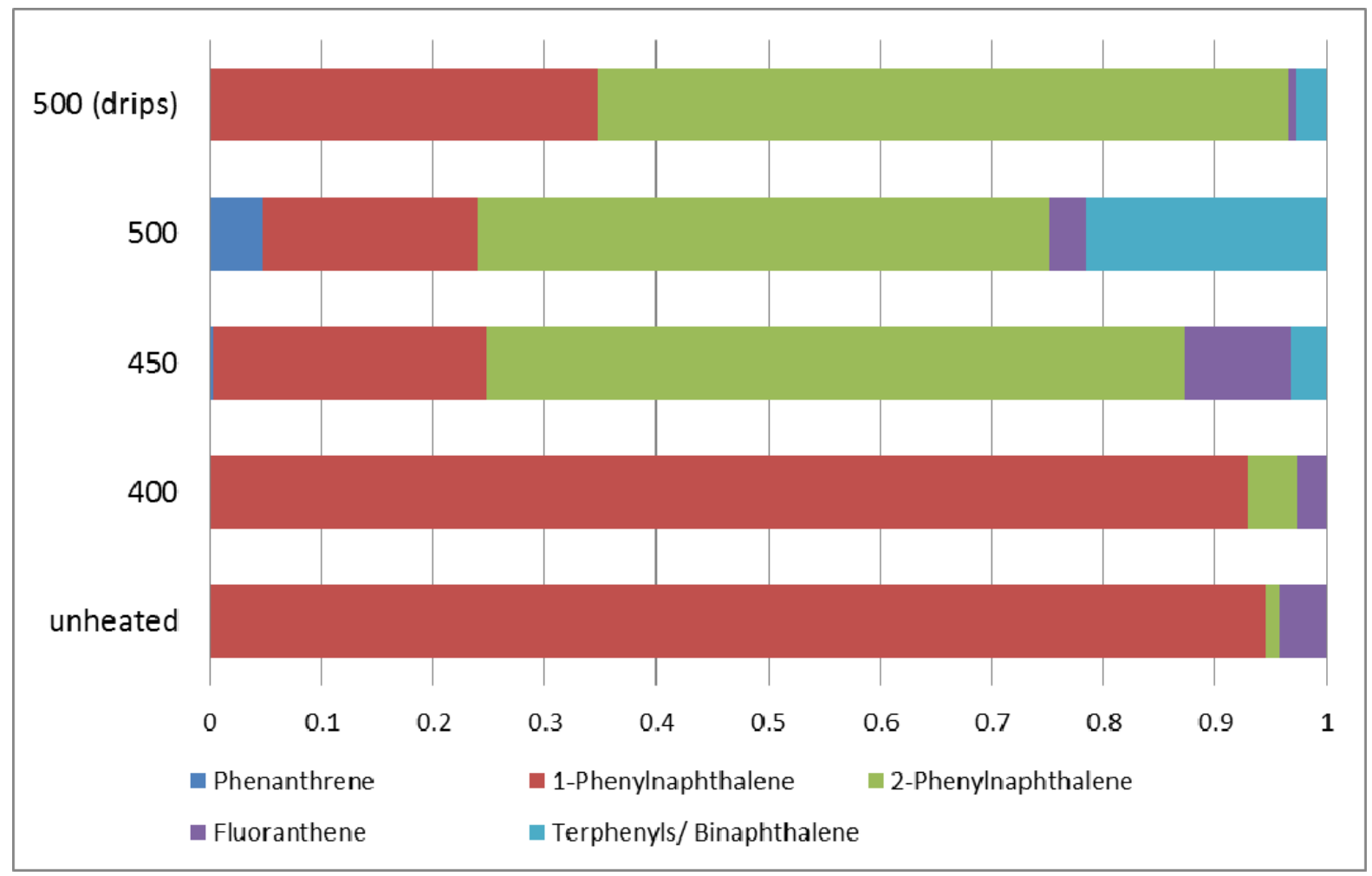

Fig. 17. Effect of temperatures on fluid heated for 1 week.

The data shown in Fig. 17 are from multiple tests involving the heating of a mixture of $95 \mathrm{wt} \%$ 1phenylnaphthalene and $5 \mathrm{wt} . \%$ fluoranthene to the temperatures on the ordinate (in ${ }^{\circ} \mathrm{C}$ ). The fractions on the abscissa indicate the concentration of product (in moles) as determined by GC-MSD analysis. These heating tests were all carried out with the fluid in contact with stainless steel or carbon steel coupons. Within the uncertainty on the measurement, there was little difference between the samples heated to $400^{\circ} \mathrm{C}$ and the unheated sample. At $450^{\circ} \mathrm{C}$, significant isomerization of the 1-phenylnaphthalene to the 2phenylnapthalene was observed, and some of the sample did rearrange to form fluoranthene and phenanthrene. At $500^{\circ} \mathrm{C}$, more chemical changes were observed. However, there was a difference in the samples that were freely flowing from the sample vessel and the residues that were rinsed out using toluene. Unsurprisingly, the sample that remained as a liquid after heating to $500^{\circ} \mathrm{C}$ (the top line labeled drips), was primarily the substituted naphthalene starting material, although rearrangement was observed. Decomposition and the release of hydrogen in the formation of fluoranthene had not occurred. For samples that were not freely flowing, there was significant chemical change after heating to $500^{\circ} \mathrm{C}$. That there appeared to be two chemically distinct samples after heating suggested that even with these small and well insulated vessels, some thermal cycling must have occurred with some of the sample experiencing a greater temperature than the other.

The effect of adding stabilizing agents was investigated, fluoranthene to reduce the rate of Reaction (1) shown earlier, and TEMPO, a radical scavenging agent. GC data are shown in Fig.18 that indicate the 
effect of adding fluoranthene, the weight percent indicated as "F" on the ordinate. As in Fig. 17 discussed earlier, the fraction of chemical species as observed by quantitative analysis is shown on the abscissa. All of these samples were heated to $500^{\circ} \mathrm{C}$ for over 1 week, except for one sample that was heated for two weeks. The presence or absence of coupons is also indicated.

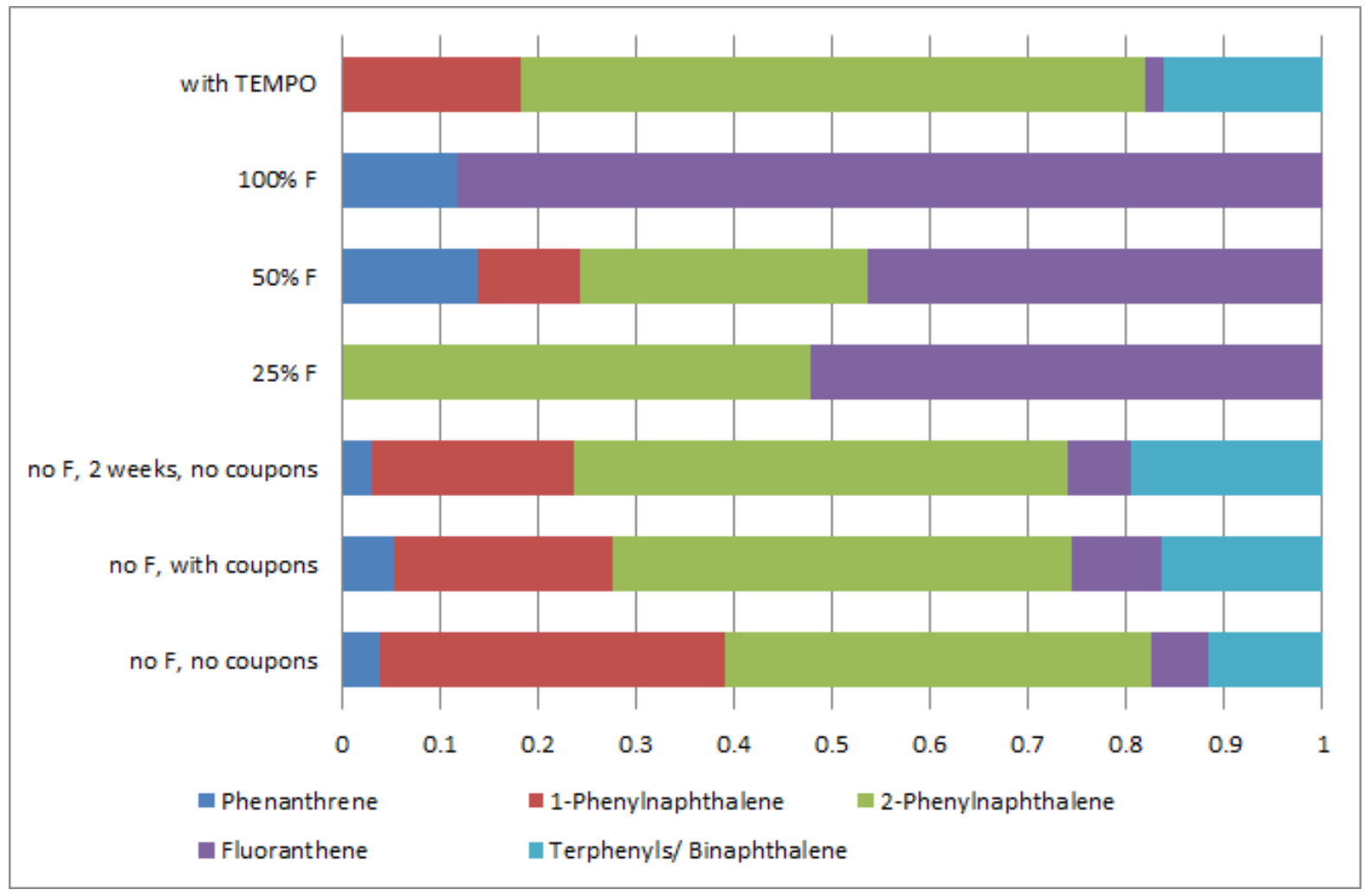

Fig. 18. GC analysis of samples after heating for 1 week at $500^{\circ} \mathrm{C}$.

The samples taken from the $500^{\circ} \mathrm{C}$ heating tests were rinsed from the vessels with toluene, hence they indicated more alteration than samples that were dripped from the vessels after heating. Samples were compared after one and two weeks of heating (the $7^{\text {th }}$ and $5^{\text {th }}$ rows down respectively) and indicated that there were continued chemical changes throughout the second week of heating, although the product fractions were not dramatically different. Tests with and without coupons of stainless steel and carbon steel indicated that the effect of the material was small. Tests using carbon steel and stainless steel were averaged as the results were so similar, within $\pm 10 \%$, or the error of the measurement. Fluoranthene converts to phenanthrene, $\mathrm{C}_{14} \mathrm{H}_{10}$, as shown by results in the second line from the top. When fluoranthene is mixed with 1-phenylnaphthalene, the isomer 2-phenylnaphthalene appears after a week of heating to $500^{\circ} \mathrm{C}$. Hence the fluoranthene does not appear to suppress the isomerization, although terphenyls and binaphthalene were not observed in the tests with large amounts of fluoranthene.

Both the static and the slow ramping experiments indicate that the 1-phenylnaphthalene fluid appears to be stable up to $450^{\circ} \mathrm{C}$, although some isomerization can occur. However, when temperatures are raised to $500^{\circ} \mathrm{C}$ and above, rearrangement to other polyaromatic hydrocarbons appears to occur over a week of heating, indicating that the fluid is beginning to break down. When the sample vessels were opened, a small amount of gas was released, although most of the sample remained a liquid. The mechanism for rearrangement has been investigated elsewhere by a computational analysis $[17,18]$ and is thought to follow a scheme as depicted in Fig. 19. 
<smiles>C=Cc1cccc2ccccc12</smiles><smiles>c1ccc(-c2cccc3ccccc23)cc1</smiles><smiles>C=C</smiles><smiles>c1ccc(-c2ccc3ccccc3c2)cc1</smiles><smiles>C=C=C</smiles><smiles>c1ccc2c(c1)-c1cccc3cccc-2c13</smiles><smiles>c1ccc2ccccc2c1</smiles><smiles>c1ccccc1</smiles>

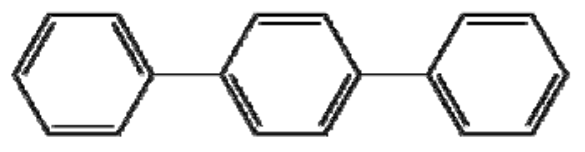<smiles>CC=CC</smiles>

Fig. 19. Fragmentation mechanism for 1-phenylnaphthalene at temperatures above $500^{\circ} \mathrm{C}$.

The $\mathrm{C}-\mathrm{H}$ bond beta to the phenyl group is the weakest and most vulnerable to breakage. Once a radical is formed, the electron can be delocalized around the aromatic ring so that isomerization does not encounter a large energy barrier. Products can include 2-phenylnaphthalene (left) or fluoranthene (right), the latter involving a net release of $\mathrm{H}_{2}$. Byproducts can include naphthalene and benzene, the latter being too small to isolate in the GC, or larger molecules such as terphenyls or binaphthalenes, which were seen to a small extent after prolonged heating to $500^{\circ} \mathrm{C}$. One way of reducing the formation of byproducts or decomposition is to add radical suppressing agents to the mixture, such as TEMPO. As show in Fig. 17, TEMPO did not affect the formation of 2-phenylnaphthalene, but did appear to reduce the formation of fluoranthene - and presumably the release of $\mathrm{H}_{2}$. If the system had reached chemical equilibrium, the addition of fluoranthene would reduce the chemical potential driving the decomposition of phenylnaphthalene. Although adding fluoranthene did affect the distribution of products, it did not prevent the decomposition and rearrangement of 1-phenylnaphthalene. Some phenanthrene was formed with an initial charge of 50 wt.\% fluoranthene and more fluoranthene was formed from a starting 
concentration of 25 wt.\% fluoranthene, suggesting that the chemical equilibrium had not yet been established in these tests even after a week of heating.

Because the results indicated that chemical reaction continued throughout a two week time period, prolonged heating experiments are planned to take place over a couple of months, to investigate the slow kinetics and perhaps achieve chemical equilibrium. Because chemical changes were observed at $500^{\circ} \mathrm{C}$, these tests will be carried out at $450^{\circ} \mathrm{C}$, a more likely operating temperature for the phenylnaphthalene fluid. In addition, light scattering will be used to investigate evidence of phase separation and solid formation over the long heating experiments, and GC-pyrolysis analysis will be used to identify off-gas species when the 1-phenylnaphthalene is heated to temperatures above $450^{\circ} \mathrm{C}$.

Candidate fluids will also be tested in an instrumented test facility that allows electrically-heated loop testing of fluids at elevated temperatures. Because the loop will involve the circulation of high temperature organic fluids, chemical safety is of utmost concern, and hazards will be minimized through engineered controls such as carrying out tests in a glovebox under an argon atmosphere. Once fluid stability has been demonstrated in the loop, a larger amount will be synthesized for use in a pilot-scale demonstration facility operated by Cool Energy Inc. Although this facility does not permit the temperature extremes expected for efficient solar trough operation, this testing is an intermediate scale operation that will further demonstrate the viability of using phenylnaphthalene as a heat transfer fluid with actual loop construction materials. It is hoped that successful demonstration of this fluid will allow it to be considered in high temperature CSP applications as another tool to achieve a reduced levelized cost of energy, to make CSP cost competitive with other routes of unconventional power generation. 


\section{REFERENCES}

1. Solutia, Therminol Vp-1. Vapor Phase/Liquid Phase Heat Transfer Fluid, in Technical Bulletin. 2008: St. Louis, MO.

2. G. Glatzmaier, Summary Report for Concentrating Solar Power Thermal Storage Workshop. New Concepts and Materials for Thermal Energy Storage and Heat-Transfer Fluids May 20, 2011. 2011, National Renewable Energy Laboratory: Golden CO.

3. J. McFarlane, H. Luo, M. Garland, and W.V. Steele, "Evaluation of Phenylnaphthalenes as Heat Transfer Fluids for High Temperature Energy Applications". Separation Science and Technology, 2010. 45: p. 1908-1920.

4. P. Rozenak and A. Loew, "Stress Distributions Due to Hydrogen Concentrations in Electrochemically Charged and Aged Austenitic Stainless Steel ". Corrosion Science, 2008. 50(11): p. 3021-3030.

5. $\quad$ D.C. Company, Dowtherm a Fluid, Na/La/Pacific. 2001: USA.

6. L.O. Oyekunle and A.A. Susu, "High Temperature Thermal Stability Investigation of Paraffinic Oil". Petroleum Science and Technology, 2005. 23.

7. W. Wagner and H.-J. Kretzschmar, International Steam Tables. 2008, Berlin: Springer.

8. M.V. Roux, M. Temprado, J.S. Chickos, and Y. Nagano, "Critically Evaluated Thermochemical Properties of Polycyclic Aromatic Hydrocarbons". J. Phys. Chem. Ref. Data, 2008. 37(4).

9. W.H. Hedley, M.V. Milnes, and W.H. Yanko, "Thermal Conductivity and Viscosity of Biphenyl and the Terphenyls". J. Chem. Eng. Data, 1970. 15(1): p. 122.

10. N. Durupt, A. Aoulmi, M. Bouroukba, and M. Rogalski, "Heat Capacities of Liquid Polycyclic Aromatic Hydrocarbons". Thermochimica Acta, 1995. 260: p. 87.

11. W. Hanshaw, M. Nutt, and J.S. Chickos, "Hypothetical Thermodynamic Properties. Subcooled Vaporization Enthalpies and Vapor Pressures of Polyaromatic Hydrocarbons". $J$. Chem. Eng. Data, 2008. 53(8).

12. C. Tsonopoulos and D. Ambrose, "Vapor-Liquid Critical Properties of Elements and Compounds. 3. Aromatic Hydrocarbons". J. Chem. Eng. Data, 1995. 40(3).

13. Solutia, Therminol 66, Unique High-Temperature, Low-Pressure Heat Transfer Fluid, in Technical Bulletin. 2004: St. Louis, MO.

14. A. Wilhelms, N. Telnæs, A. Steen, and J. Augustson, "A Quantitative Study of Aromatic Hydrocarbons in a Natural Maturity Shale Sequence-the 3-Methylphenanthrene=Retene Ratio, a Pramatic Maturity Parameter.". Org. Geochem., 1998. 29(1-3).

15. W.H. Orem, C.A. Tatu, H.E. Lerch, C.A. Rice, T.T. Bartos, A.L. Bates, S. Tewalt, and M.D. Corum, "Organic Compounds in Produced Waters from Coalbed Natural Gas Wells in the Powder River Basin, Wyoming, USA". Applied Geochemistry, 2007. 22.

16. Schott, Schott Ptr70 Receiver. The Next Generation. 2009.

17. J. Cioslowski, P. Piskorz, and D. Moncrieff, "Thermally Induced Cyclodehydrogenation of Biaryls: A Simple Radical Reaction of a Sequence of Rearrangements?". J. Org. Chem., 1998. 63: p. 4051-4054.

18. J. Cioslowski, G. Liu, M. Martinov, P. Piskorz, and D. Moncrieff, "Energetics and Site Specificity of the Homolytic C-H Bond Cleavage in Benzenoid Hydrocarbons: An Ab Initio Electronic Structure Study". J. Am. Chem. Soc., 1996. 118: p. 5261-5264. 
Appendix A

DETAILS ON THE HEATING EXPERIMENTS 




\section{Appendix A. DETAILS ON THE HEATING EXPERIMENTS}

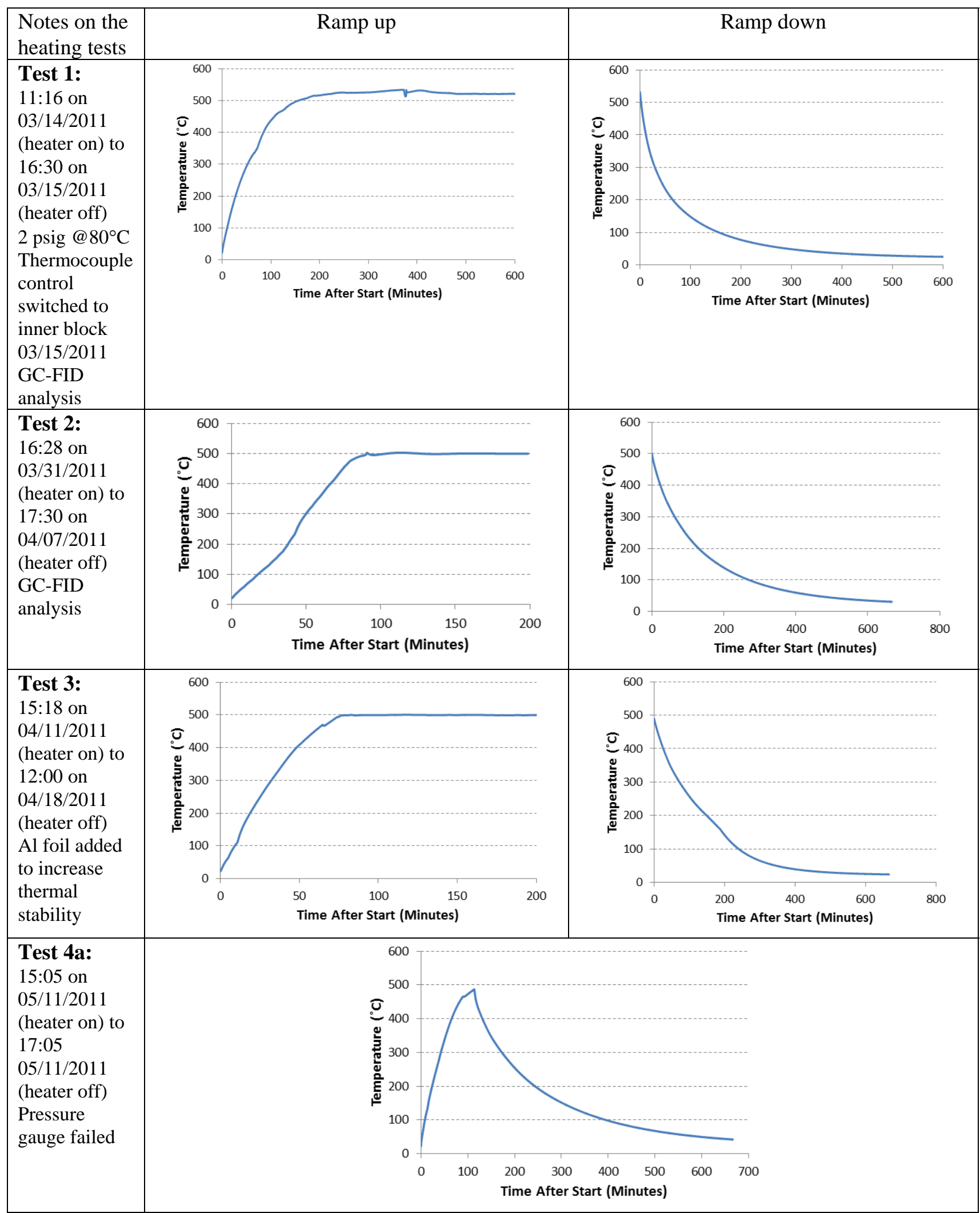




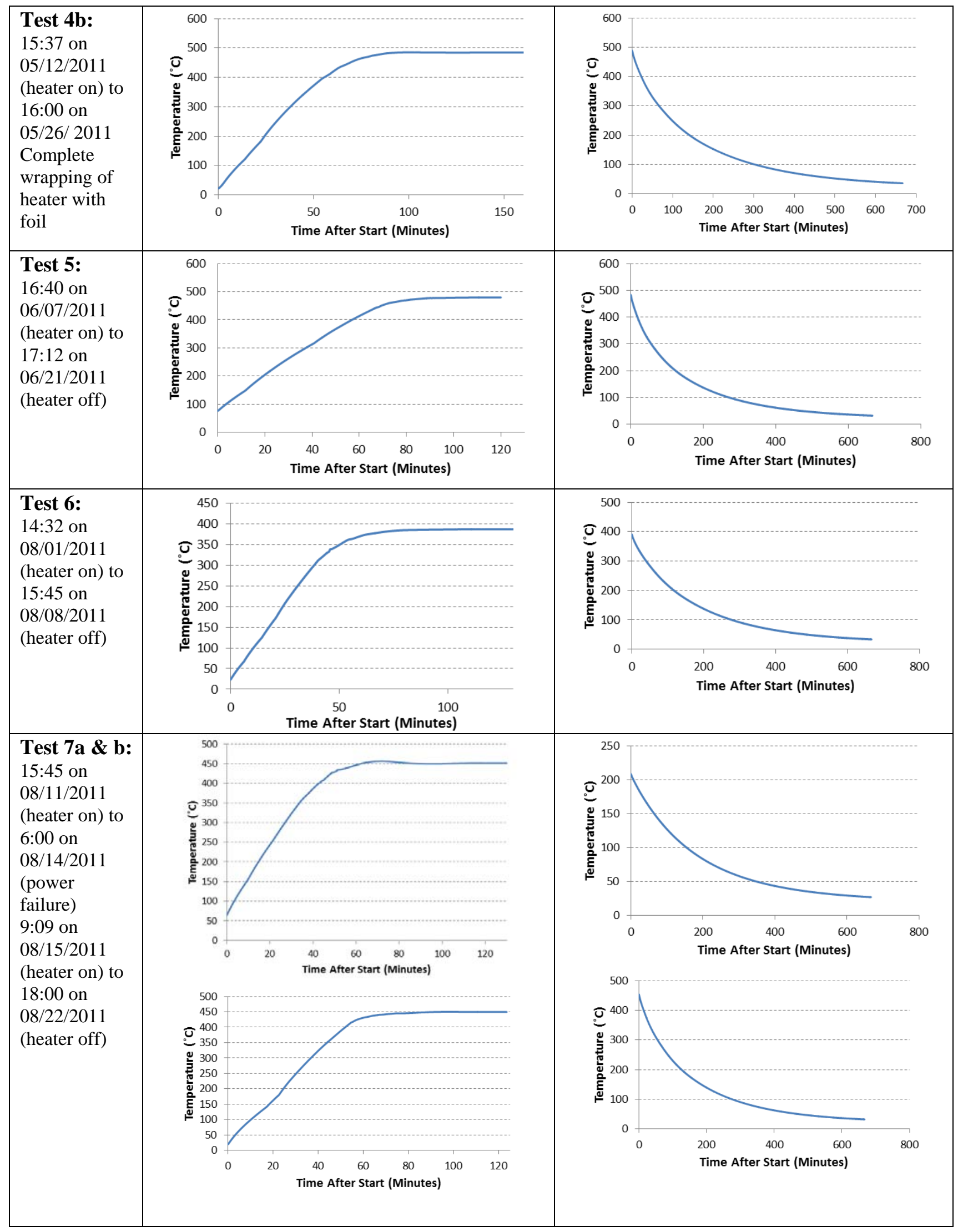




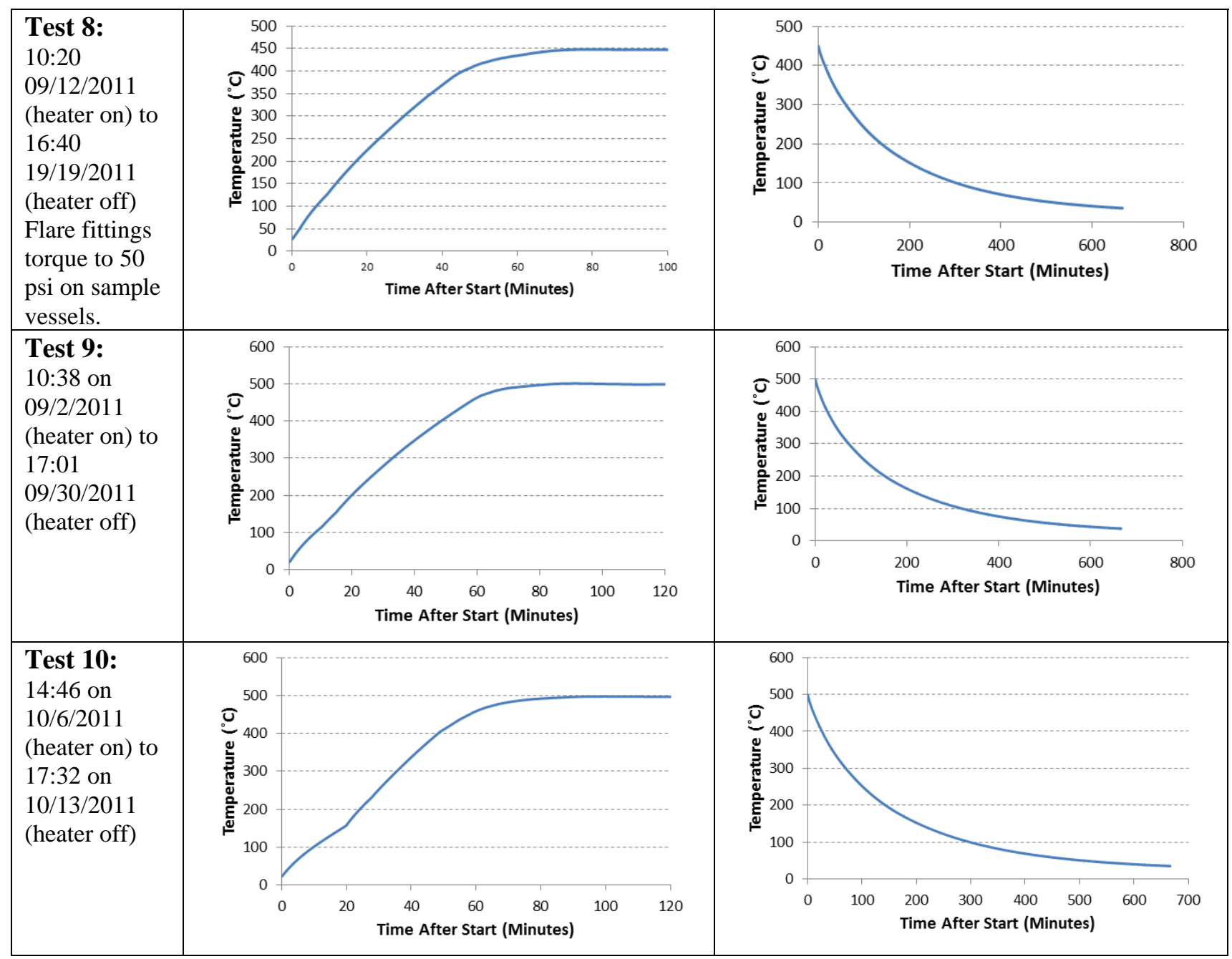


Appendix B

QUANTIZATION OF GAS CHROMATOGRAPHIC ANALYSIS 




\section{Appendix B. QUANTIZATION OF GAS CHROMATOGRAPHIC ANALYSIS}

Samples of 1-phenylnaphthalene and fluoranthene were prepared by adding the solid (the fluoranthene) into the liquid phenylnaphthalene. The mixture was sonicated for three min to bring the compounds into solution. The mass fractions were converted to moles. The samples were diluted and $1 \mathrm{uL}$ were injected into the GC-FID and into the GC-MSD. Integration of the areas under the peaks were plotted and a linear least squares analysis was done.
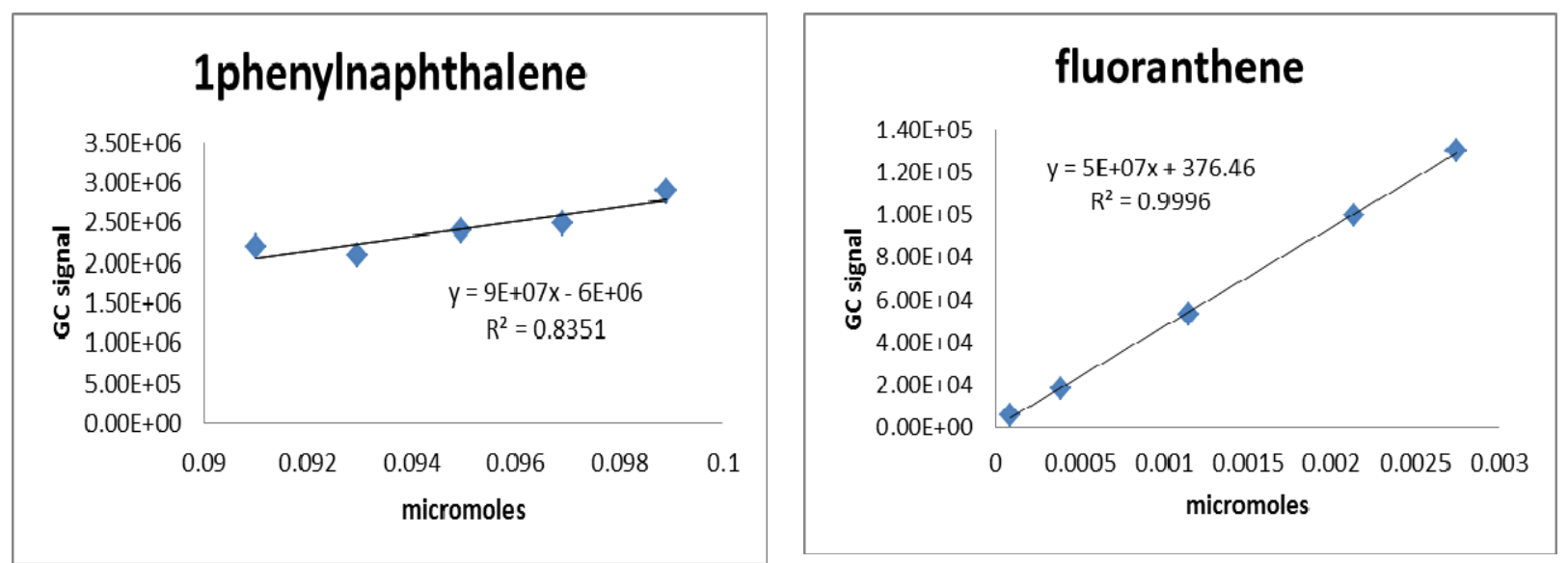

Fig. B-1. Calibration curves for signal from GC-FID.

As can be seen from the graphs above, the signal from the GC-FID was reasonably linear, especially in the smaller component, the fluoranthene. However, the phenylnaphthalene signal from the GC-MSD was not proportional to concentration because of detector saturation. That the GC-FID gives better quantitation is expected, and hence, whenever possible, samples were run on both instruments, the GCMSD allowing identification of the chromatographic peaks through the ion fragmentation patterns.
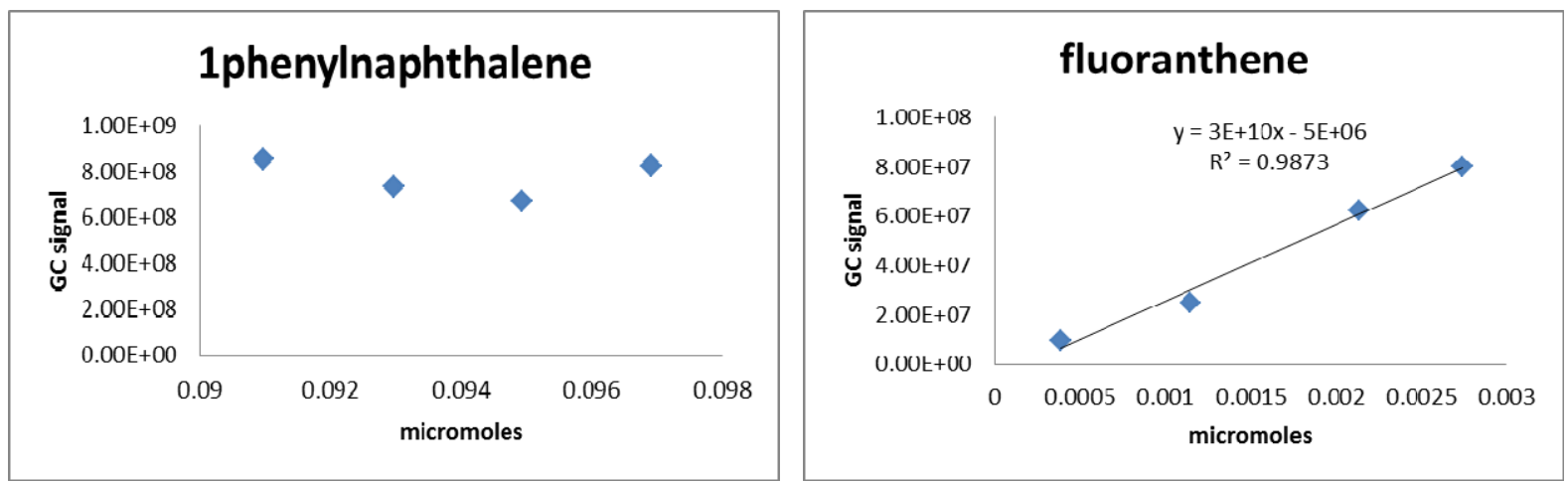

Fig. B-2. Calibration curves for signal from GC-MSD. 




\section{INTERNAL DISTRIBUTION}

1. J.R. Bell

2. C. Duty

3. R. Joseph, III

4. J. McFarlane

5. A.L. Qualls
6. ORNL Office of Technical Information and Classification

\section{EXTERNAL DISTRIBUTION}

7. L. Irwin, Department of Energy, Solar Energy Tecnology Program, 950 L’Enfant Plaza SW, Washington, DC, 20585

8. J. Stekli, Department of Energy, Solar Energy Tecnology Program, 950 L’Enfant Plaza SW, Washington, DC, 20585

9. R. Pitchumani, Department of Energy, Solar Energy Tecnology Program, 950 L'Enfant Plaza SW, Washington, DC, 20585

10. S.P. Weaver, Cool Energy Inc., 5541 Central Avenue \#172, Boulder, CO, 80301. 